\title{
Qualitative research practices and family business scholarship: A review and future research agenda
}

\author{
Denise Fletcher ${ }^{\mathrm{a}}$, Alfredo De Massis ${ }^{\mathrm{b}, *}$, Mattias Nordqvist $^{\mathrm{c}}$ \\ a Professor of Entrepreneurship and Innovation, University of Luxembourg 148 avenue de la Faiencerie, L-1511 Luxembourg \\ ${ }^{\mathrm{b}}$ Professor of Entrepreneurship and Family Business, Director, Centre for Family Business, Department of Entrepreneurship, Strategy and Innovation, Lancaster \\ University Management School, Lancaster LA1 4Y, UK \\ c Professor of Business Administration, Director, Center for Family Enterprise and Ownership (CeFEO), Jönköping International Business School, Jönköping \\ University, P.O. Box 1026 SE-551 11 Jönköping, Sweden
}

\section{A R T I C L E I N F O}

Article history:

Received 11 March 2015

Received in revised form 20 July 2015

Accepted 4 August 2015

\section{Keywords:}

Qualitative research

Qualitative methods

Epistemology

Interpretivism

Family business

Future research

\begin{abstract}
A B S T R A C T
In spite of various calls for a wider application of qualitative research in the family business field, it is our contention that the full potential of qualitative inquiry is not being fully realized. Part of the reason for this relates to the tendency to promote methods choice and diversity rather than addressing the foundational questions and processes which underlie qualitative research choices. These tendencies obscure attention to the reasons why researchers choose qualitative methods and the kinds of foundational issues about family businesses that are brought to light through qualitative research. To address this, we undertake an analysis of the most-cited articles using qualitative methods from an annotated bibliography of family business studies. From this, we identify the strengths and weaknesses of extant qualitative studies in family business research and argue for the need to re-orientate calls in family business research towards the foundational questions (rather than methods) that underline qualitative inquiry.
\end{abstract}

(c) 2015 Elsevier Ltd. All rights reserved.

\section{Introduction}

In spite of various calls for improvements in the use and communication of qualitative research approaches in family business research (Chenail, 2009; De Massis \& Kotlar, 2014; Nordqvist, Hall, \& Melin, 2009; Reay \& Zhang, 2014), qualitative inquiry is still relatively under-realized in published research output. An analysis of the 215 most-cited family business studies from the annotated bibliography by De Massis, Sharma, Chua, \& Chrisman (2012), for example, reveals that the majority of empirical studies are quantitative (87.3\%), with only a minority of articles (18) relying on qualitative methods (8.4\%). Also, in a literature review by Reay and Zhang (2014), the authors identified 78 articles from a possible 656 in their sample that used qualitative methods.

This under-utilization of qualitative methods is surprising for at least two reasons. First, the tradition of family business research has

\footnotetext{
* Corresponding author at: Institute for Entrepreneurship and Enterprise Development, Lancaster University Management School, Lancaster, LA1 4YX, UK.

E-mail addresses: denise.fletcher@uni.lu (D. Fletcher),

a.demassis@lancaster.ac.uk (A.D. Massis), mattias.nordqvist@jibs.hj.se (M. Nordqvist)
}

strong roots in business history, economic sociology and social anthropology where a wide range of research tools often associated with qualitative research (such as ethnography, participant observation and family memoirs archives/photographs/diaries), have been employed (Colli, 2012; Stewart, 2003, 2014). Second, the underrealization of qualitative methods is also surprising given the surge of interest in qualitative inquiry in other areas of organization studies (Buchanan \& Bryman, 2009) including the general management field (Alvesson \& Deetz, 2000; Corley, 2011; Pratt, 2009; Thorpe \& Holt, 2008) and sub-fields such as entrepreneurship (Neergaard \& Ulhøi, 2007) and strategy (Fenton \& Langley, 2011). Such discussion, as noted by Alvesson \& Sköldberg (2000, p.4) referring to Silverman (1985); Denzin and Lincoln (1994), means that qualitative methodological discussions are well developed in other areas of the social sciences to the point that they even predominate in some.

In the specific domain of family business research, however, the full potential of qualitative research practices is not yet fully being realized. Many authors refer to the aptness of qualitative methods for studying human behaviors, fine-grained processes and the complex and tacit processes that characterize family firms (Melin \& Nordqvist, 2007; Nordqvist et al., 2009; Fletcher, 2014; Reay \& Zhang, 2014; Zellweger, 2014). Some refer to traditions from sociology (Martinez \& Aldrich, 2014), anthropology (Stewart, 2014), family science (Jennings, Breitkreuz, \& Jones, 2014) and 
psychology (Von Schlippe \& Schneewind, 2014) to raise new directions, theories and methods for family business research. But still we lack detailed understanding of what Miller et al. (2015) refer to as the 'Janus-faced' nature of family firms and their associated dualistic (Jackson, 1999) and paradoxical tendencies (Lewis, 2000; Smith \& Lewis, 2011).

This lack of full realization of the potential of qualitative research practices can be partly explained by the tendency to refer to 'qualitative methods' as if there is a readily available repository of identifiable qualitative methods, tools and techniques that can be drawn upon to aid certain kinds of analysis. In family business research, for example, recent articles have called for improvements in the use, rigor and communication of qualitative methods (Chenail, 2009; Reay \& Zhang, 2013; Reay, 2014). Reay and Zhang (2013, p. 28) encourage researchers to develop 'well designed and appropriately-implemented qualitative studies' for developing theory. Also, in Reay and Zhang (2014), seven strategies for getting qualitative research published are outlined. Such commentaries help to encourage more systematic usage and technical production of qualitative methods and better communication of qualitative research strategies. An issue that is somewhat overlooked, however, is why family business researchers choose to adopt qualitative methods and what kinds of issues and processes they are trying to uncover.

Using the term 'qualitative methods' appears to be useful for signaling the use of discursive and context sensitive fieldwork material as distinct from numerical data. It is clear that they offer a series of techniques or methods for examining discursivity, dynamic processes, complexity, contextualization, relationality and fine-grained detail. But to what extent do we fully extend the potential of research methods for examining the nuances of these processes in family business settings for examining paradox, contradictions and dualities? Also, it is reported that qualitative methods are 'powerful tools' for developing theory (Reay \& Zhang, 2014 , p.5) but in what ways can we engage more directly with qualitative methods to develop theory? Furthermore, in referring to the term 'qualitative methods', this tends to assume that there is 'a fixed battery of methods' (Stewart, 2014 p.77 referring to Malkki, 2007, p. $180^{1}$ ) that can be drawn upon to fill in gaps or explore unknown phenomena. In research practice, however, qualitative inquiry encapsulates 'multiple practices . . . and vocabularies ... which acquire different meanings in their use' which means that they 'form something more like a constellation of contested practices' (Patton, 2002p.76 referring to Schwandt, 1997 p.xiv) rather than a finite list of proven tools and techniques. This diversity and the lack of a fixed template or 'boilerplate' (Pratt, 2009) for undertaking qualitative research means that there is more emphasis on technical improvement of qualitative methods rather than the scholarship potential of qualitative inquiry.

In this article, our concern is to re-orientate family business research interests towards the foundational questions (rather than methods) that underline qualitative inquiry. We argue that in addressing these foundational questions through qualitative research certain issues about family businesses are brought to light. Moreover, not only does this encourage a qualitatively oriented social science that is 'methodologically sound' but it also moves us in the direction of realizing methods that 'are [well] suited to family business studies' (Stewart, 1998, 2014, p.67).

In what is to follow, we undertake an analysis of the most-cited articles from an annotated bibliography of family business studies that have adopted a qualitative method or mode of inquiry. In Section 2, we outline the significance and meaning of qualitative

\footnotetext{
1 These authors are both referring to ethnography but the same argument applies to qualitative methods.
}

research. Then, we review the kinds of research questions and topics being investigated with the use of qualitative methods, identifying their strengths and limitations. Finally, we provide a framework for re-orientating family business researchers to the foundational questions underlying qualitative methods choices. We conclude with suggestions for new and fruitful lines of inquiry for family business research with a view to fully extending the potential of qualitative research for addressing issues of contradiction and paradox in family business.

\section{What is the challenge and why do we need more scrutiny about qualitative research practice in family business research?}

Two decades ago, Levin (1993) argued for the significance of moving from close and non-problematized views of family to perspectives and approaches which try to accommodate the complex issues drawn from the everyday experience and interpretations of family business members and employees. Since then various efforts to address the nuanced and complex social realities of family firms have been made. These include: work on notions of 'familiness' or family influence to highlight the special cultures, values, orientations, 'living moments', emotions and particular ways of organizing (De Massis \& Kotlar, 2014; Melin \& Nordqvist, 2007; Brundin \& Nordqvist, 2008; Helin, 2011); efforts to stress the specificity and complexity of family businesses (Fletcher, 2004; Nordqvist et al., 2009, p. 294) using, for example, concepts of 'collective mindfulness' (Zellweger, 2014), as well as studies on the social relations or kinship patterns in groups, communities and societies (Stewart, 2003).

Such inquiries are distinctive because they tend to be less driven by empiricist techniques searching for 'data' and linear causal explanations that enable prediction. Instead, they are more concerned with understanding and reconstructing activities as they occur in practice in a particular socio-cultural-political context. For example, in making a plea for 'an imagined ideal' Stewart (2014, p.66) orientates researchers towards the kinship (rather than business) side of family business matters in order to give 'attention to the sources of solidarity and conflict, to cultural variation and to the lived experience of kinship' (p.66). A further example is Ainsworth and Cox, (2003) where the authors encourage us to examine issues of resistance, control, consensus, dissensus, subordination and asymmetrical relations as they shape family firm activity or behaviors. Zellweger (2014) also advances our thinking to go beyond the dualism perspective of family firms by drawing attention to the 'power of anomalies and paradoxes' (p.653). Conceptually, he introduces family businesses researchers to the notion of 'collective mindfulness' as a means to understand how families manage and negotiate synergies between family and firm dualities. A paradox or duality perspective is relevant for family business research because it simultaneously considers two opposite principles which might form an entity without becoming a unity (Jackson, 1999; Lewis, 2000). Examples of paradoxes from the family business literature are: family and enterprise (Fletcher, 2000), or 'family and business', 'private and public', and 'informality and formality' (Nordqvist, 2012). Another example is the ability and willingness paradox in family firm innovation (Chrisman, Chua, De Massis, Frattini, \& Wright, 2015). These perspectives imply that analyzing just one pole of the duality or paradox does not capture its underlying logic. Moreover, these research efforts signify a demand in family business research to understand complexity and to give 'voice and legitimacy to those tacit and oftentimes unpresentable forms of knowledge that modern epistemology inevitably depends upon, yet conveniently overlooks or glosses over' (Chia, 2008, p.162).

Qualitative inquiry is particularly appropriate for understanding contradictions, tensions, paradoxes and dualities in family 
businesses because they endeavor to capture the individualized, relational, processual and contextual nature of a phenomenon. Over time, therefore, the term 'qualitative research' has become a familiar and useful shorthand term for signifying research tools and techniques that privilege family business processes that cannot easily be quantified or codified using numerical classifications (i.e. interpretation processes, sense-making, meaningmaking, situated actions, discursive constructions, processes, contextual factors, interactions or inter-personal dynamics). When we engage in research qualitatively, therefore, our aspiration is to emphasize discursive, as well as numerical data, in order to understand the socially experienced meanings, understandings and sense making processes of social actors and to get at the exceptions, [and] the outliers (Thorpe \& Holt, 2008, p.4). To use Miles \& Huberman (1994, p.6) wording, qualitative research practices strive, therefore, to 'represent and order the logic, arrangement and structuring of relationships, patterns and rules in relation to context'. They also bring to the surface the various contexts of our research practice whether ethical, institutional or political (Buchanan \& Bryman, 2009).
In view of this range of interests, qualitative modes of inquiry offer a wide range of research tools, methods and theoretical orientations. Researchers can choose from an array of naturalistic methods (i.e., ethnography, participant observation, grounded theory, ethnomethodology), to participative methods for engaging in research (i.e., collaborative research, social construction) or methods that focus on understanding, interpretation and sensemaking (i.e. hermeneutics, phenomenology). Each method and theoretical orientation brings different nuances and can help to explore, examine or be alert to interpretations, relationships, conversations, interactions, situated meanings, sensemaking processes as they occur in situ or context.

In family business research, however, although we can observe a range of methods in use, we rarely see attention to, or discussion of, the foundational questions shaping qualitative research choices. Being explicit about the foundational questions underlying our research choices helps a reconnection to the fundamental meanings and purpose of qualitative research. Such scrutiny would also enable examination of the 'micro-foundations' (Gagné, Sharma, \& De Massis, 2014; Zahra, Wright, \& Abdelgawad, 2014) of family

Table 1

Key features of qualitative research and distinctive traits in the family business field.

\begin{tabular}{l} 
Interests and preoccupations \\
\hline i. To explicate the ways in which people come to understand, account for, take action \\
and manage their day-to-day situations from the inside.
\end{tabular}

Strengths/limitations in qualitative family business research ${ }^{* *}$

and manage their day-to-day situations from the inside.

Some attention to individual perspective but insufficient detailed attention to the daily life of social actors and detailed understanding of their sense-making or interpretations.

Lack of explicit attention to contextual factors in shaping insights.

Context assumed to be embedded in insights and not used to explain outcomes.

Tendency to aggregate and reify personal accounts to organizational or firm level to explain outcomes.

Lack of close study of group interactions and relational dynamics.

ii. To see things in context and gain a holistic overview of the context under study. A concern for holistic perspectives to account for dynamics.

And to work out the logic, arrangement and structuring of relationships, patterns Strong use of case studies to work out arrangements and inter-relationships and rules (whether explicit or implicit) in relation to context. between factors. Recurring use of multiple sources of data to understand complexity. Limited use of methods to undertake repeated interactions in fieldwork studies over time.

Tendency to reduce complexity and dynamics to a simple set of causal relationships devoid of context.

Lack of use of process modes of inquiry to observe flux, change, movement and flow of organizational life.

iii. To elucidate the sense-making accounts, behaviors, interactions, relationship patterns and structures reported during fieldwork.

Use of direct quotations from respondents to show authentic experience. Examples of displaying and reducing extensive amounts of data.

And to maintain field work accounts in their original forms throughout the study. Linguistic phrases are presented as objectified collections of words devoid of contextual explanation.

Overlooks the role of language and discourse in constituting meaning. Opportunities to 'go deeper' to examine subtle cultural, political or structural issues are overlooked.

iv. To acknowledge the role that the researcher has in the research process.

Lack of transparency and detailed discussion of audit trails showing analytical processes and theory development.

Lack of reflexivity and transparency on the role of the qualitative inquirer in gaining access to fieldwork, building rapport, and undertaking analysis. Absence of sharing fieldwork findings with respondents.

v. Theory development is iterative rather than sequential and many interpretations Efforts to report new theory through qualitative methods - i.e. describing and are possible but some are more compelling for theoretical reasons or on grounds of exploring what is not usually seen. internal consistency.

Use of theoretical propositions to extend existing theory. Efforts to introduce new concepts and conceptualizations.

Lacking detail on what it means to develop theory through iterative processes. Difficult for reviewers to assess how theoretical insights or new theories are claimed.

Too much effort to trace specific outcome variables to preselected predicted correlations.

Tendencies to over-simplify complexity and dynamics to a set of simple causal relationships devoid of context.

Too much effort attached searching for a single truth or explanation (rather than emphasizing multiple truths).

Philosophical roots seldom made explicit.

\footnotetext{
"Categories adapted from Miles and Huberman (1994, pp.6-7).

As emerged from our review of the most cited qualitative studies.
} 
The family business qualitative studies articles evaluated in our study

\begin{tabular}{|c|c|c|c|c|c|c|c|c|c|c|}
\hline Study & Research question & Study subject & Site selection & $\begin{array}{l}\text { Qualitative } \\
\text { method chosen }\end{array}$ & $\begin{array}{l}\text { Theoretical } \\
\text { purpose and } \\
\text { rationale }\end{array}$ & Source of data collection & Analysis \& interpretation & $\begin{array}{l}\text { Presentation } \\
\text { of results }\end{array}$ & $\begin{array}{l}\text { Development of } \\
\text { propositions }\end{array}$ & \\
\hline $\begin{array}{l}\text { Bagwell } \\
\text { (2008) }\end{array}$ & $\begin{array}{l}\text { How do Vietnamese } \\
\text { businesses in the } \\
\text { nail-shop sector } \\
\text { make use of their } \\
\text { networks? What } \\
\text { role might these } \\
\text { networks play in } \\
\text { facilitating or } \\
\text { hindering } \\
\text { diversification? }\end{array}$ & $\begin{array}{l}\text { Vietnamese } \\
\text { transnational family } \\
\text { networks in the nail- } \\
\text { shop sector. }\end{array}$ & $\begin{array}{l}\text { Eight nail-shop owner- } \\
\text { managers, a former nail-shop } \\
\text { owner running a Japanese } \\
\text { restaurant when the study was } \\
\text { conducted, and the main } \\
\text { Vietnamese nail-shop supplier } \\
\text { in London. Interviews were also } \\
\text { held with a Vietnamese } \\
\text { business advisor and three key } \\
\text { informants from the } \\
\text { Vietnamese community in } \\
\text { order to obtain an overview of } \\
\text { the Vietnamese business } \\
\text { community as a whole and the } \\
\text { key issues (cultural and } \\
\text { structural) facing it. }\end{array}$ & $\begin{array}{l}\text { Multiple case } \\
\text { study. }\end{array}$ & $\begin{array}{l}\text { Theory } \\
\text { building - } \\
\text { Exploratory } \\
\text { (need for } \\
\text { understanding } \\
\text { HOW) }\end{array}$ & $\begin{array}{l}\text { Direct interviews (semi- } \\
\text { structured, face-to-face } \\
\text { interviews with owner- } \\
\text { managers) } \\
\text { Observations }\end{array}$ & $\begin{array}{l}\text { Analysis of the interview } \\
\text { transcripts with the help of } \\
\text { NVivo software to identify } \\
\text { emergent themes. }\end{array}$ & Quotes & No & $\begin{array}{l}0 \\
0 \\
\frac{1}{2} \\
\frac{1}{3} \\
0 \\
0 \\
0 \\
0\end{array}$ \\
\hline $\begin{array}{l}\text { Chirico, F. \& } \\
\text { Nordqvist } \\
\text { (2010) }\end{array}$ & Not specified & $\begin{array}{l}\text { Organizational } \\
\text { culture and } \\
\text { transgenerational } \\
\text { value creation in } \\
\text { family firms. }\end{array}$ & $\begin{array}{l}\text { Two family firms from Italy and } \\
\text { two from Switzerland, all } \\
\text { operating in the beverage } \\
\text { industry. }\end{array}$ & $\begin{array}{l}\text { Multiple case } \\
\text { study. }\end{array}$ & $\begin{array}{l}\text { Theory } \\
\text { building - } \\
\text { Exploratory } \\
\text { (need for } \\
\text { understanding } \\
\text { HOW) }\end{array}$ & $\begin{array}{l}\text { Multiple direct interviews } \\
\text { (with two respondents from } \\
\text { different generations in each } \\
\text { firm) } \\
\text { Observations } \\
\text { Secondary sources } \\
\text { (newspapers and magazine } \\
\text { articles, internal documents, } \\
\text { slide presentations, press } \\
\text { releases, websites and balance } \\
\text { sheets) }\end{array}$ & $\begin{array}{l}\text { Creation of a database with } \\
\text { interview and secondary } \\
\text { sources data; } \\
\text { Writing of case descriptions; } \\
\text { Within case and cross case } \\
\text { analyses (coding and analysis of } \\
\text { ach case description } \\
\text { individually and then in } \\
\text { comparison) }\end{array}$ & $\begin{array}{l}\text { Quotes } \\
\text { Figures/ } \\
\text { frameworks }\end{array}$ & No & 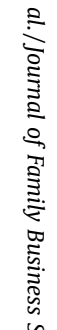 \\
\hline Cole (1997) & $\begin{array}{l}\text { How do gender- } \\
\text { related issues affect } \\
\text { family members' } \\
\text { work? }\end{array}$ & $\begin{array}{l}\text { The experiences of } \\
\text { women in family } \\
\text { firms. }\end{array}$ & $\begin{array}{l}23 \text { family members ( } 12 \text { females } \\
\text { and } 11 \text { males) across } 9 \text { US firms. }\end{array}$ & $\begin{array}{l}\text { Naturalistic/ } \\
\text { constructivistic } \\
\text { research }\end{array}$ & $\begin{array}{l}\text { Theory } \\
\text { building - } \\
\text { Exploratory } \\
\text { (need for } \\
\text { understanding } \\
\text { HOW) }\end{array}$ & Direct Interviews & Constant comparative method & $\begin{array}{l}\text { Quotes } \\
\text { Tables }\end{array}$ & No & 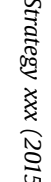 \\
\hline $\begin{array}{l}\text { De Massis, } \\
\text { Frattini, } \\
\text { Pizzurno, } \\
\text { \& Cassia } \\
(2013)\end{array}$ & Not specified & $\begin{array}{l}\text { Product innovation } \\
\text { management in } \\
\text { family versus } \\
\text { nonfamily firms. }\end{array}$ & $\begin{array}{l}\text { Ten Italian small firms } \\
\text { operating in different } \\
\text { industries that are well } \\
\text { respected for their prowess and } \\
\text { success in the area of product } \\
\text { innovation (five of which are } \\
\text { family and five non-family } \\
\text { businesses). }\end{array}$ & $\begin{array}{l}\text { Multiple case } \\
\text { study. }\end{array}$ & $\begin{array}{l}\text { Theory } \\
\text { building - } \\
\text { Exploratory } \\
\text { and } \\
\text { explanatory } \\
\text { (need for } \\
\text { understanding } \\
\text { HOW and } \\
\text { WHY) }\end{array}$ & $\begin{array}{l}\text { Multiple direct interviews } \\
\text { (more than } 35 \mathrm{~h} \text { of semi- } \\
\text { structured interviews with at } \\
\text { least two informants for ach } \\
\text { firm) } \\
\text { Secondary sources (company } \\
\text { documents, catalogues, project } \\
\text { documentation, family } \\
\text { information) }\end{array}$ & $\begin{array}{l}\text { Data categorization and } \\
\text { contextualization techniques; } \\
\text { Within-case analysis; } \\
\text { Explanation-building } \\
\text { investigation; } \\
\text { Cross-case analysis }\end{array}$ & $\begin{array}{l}\text { Quotes } \\
\text { Tables } \\
\text { Figures/ } \\
\text { frameworks }\end{array}$ & No & $\begin{array}{l}0 \\
x \\
x \\
x \\
x \\
x \\
x\end{array}$ \\
\hline $\begin{array}{l}\text { DeAngelo \& } \\
\text { DeAngelo } \\
\text { (2000) }\end{array}$ & $\begin{array}{l}\text { Do the payout policy } \\
\text { and the pressure for } \\
\text { dividends of main } \\
\text { block stockholders } \\
\text { influence corporate } \\
\text { governance? }\end{array}$ & $\begin{array}{l}\text { The role of payout } \\
\text { policy and dividend } \\
\text { pressure made by } \\
\text { stockholders on } \\
\text { corporate } \\
\text { governance of a } \\
\text { family-owned public } \\
\text { family firm. }\end{array}$ & $\begin{array}{l}\text { The Times Mirror Company, a } \\
\text { NYSE-listed Fortune } 500 \text { family } \\
\text { firm controlled for } 100 \text { years by } \\
\text { the Chandler family. }\end{array}$ & $\begin{array}{l}\text { Single case } \\
\text { study. }\end{array}$ & $\begin{array}{l}\text { Theory } \\
\text { building - } \\
\text { Descriptive }\end{array}$ & Secondary sources & Not explicitly specified & $\begin{array}{l}\text { Quotes } \\
\text { Tables }\end{array}$ & Yes & \\
\hline
\end{tabular}




\begin{tabular}{|c|c|c|c|c|c|c|c|c|c|}
\hline $\begin{array}{l}\text { Dyck, } \\
\text { Mauws, } \\
\text { Starke, \& } \\
\text { Mischke } \\
(2002)\end{array}$ & $\begin{array}{l}\text { What factors } \\
\text { influence successful } \\
\text { successions in } \\
\text { family firms? }\end{array}$ & $\begin{array}{l}\text { Executive } \\
\text { succession } \\
\text { considered as a } \\
\text { process similar to } \\
\text { "passing the baton" } \\
\text { in a relay race. }\end{array}$ & $\begin{array}{l}\text { Real-time analysis of a failed } \\
\text { executive succession in a } \\
\text { privately-held family firm } \\
\text { operating in the manufacturing } \\
\text { industry. }\end{array}$ & $\begin{array}{l}\text { Single case } \\
\text { study. }\end{array}$ & $\begin{array}{l}\text { Theory } \\
\text { building - } \\
\text { Exploratory } \\
\text { and } \\
\text { Explanatory } \\
\text { (need for } \\
\text { understanding } \\
\text { HOW and } \\
\text { WHY) }\end{array}$ & $\begin{array}{l}\text { Direct interviews (ten in-depth } \\
\text { interviews about } 1-2 \mathrm{~h} \text { each } \\
\text { with incumbent and successor } \\
\text { CEOs) }\end{array}$ & $\begin{array}{l}\text { Inductive data analysis by } \\
\text { carefully working through the } \\
\text { interview } \\
\text { transcripts numerous times (cf. } \\
\text { Handler, 1990, 1992), followed } \\
\text { by data categorization and } \\
\text { identification of common } \\
\text { themes. }\end{array}$ & $\begin{array}{l}\text { Quotes } \\
\text { Table } \\
\text { Figures/ } \\
\text { frameworks }\end{array}$ & Yes \\
\hline $\begin{array}{l}\text { Fletcher } \\
(2010)\end{array}$ & Not specified. & $\begin{array}{l}\text { Co-habiting couples } \\
\text { developing family } \\
\text { business start-ups } \\
\text { (co-preneurship). }\end{array}$ & $\begin{array}{l}\text { Twenty-six couple in the North } \\
\text { Nottinghamshire, in UK. Each } \\
\text { couple was at the centre of the } \\
\text { business venture. }\end{array}$ & $\begin{array}{l}\text { Fieldwork study } \\
\text { based on } \\
\text { interview data. }\end{array}$ & $\begin{array}{l}\text { Theory } \\
\text { building - } \\
\text { Exploratory } \\
\text { (need for } \\
\text { understanding } \\
\text { HOW) }\end{array}$ & $\begin{array}{l}\text { Direct and telephone } \\
\text { interviews (with } 26 \text { couples } \\
\text { involved in business ventures) }\end{array}$ & $\begin{array}{l}\text { Identification of themes } \\
\text { through conceptual coding of } \\
\text { the interview transcripts; } \\
\text { Assessment of the relevance of } \\
\text { the types of co-preneurial } \\
\text { categories in the typology; } \\
\text { Identification of key } \\
\text { characteristics of the firm }\end{array}$ & $\begin{array}{l}\text { Tables } \\
\text { Figures/ } \\
\text { frameworks }\end{array}$ & $\begin{array}{l}\text { No (but the author } \\
\text { proposes a } \\
\text { reformulated } \\
\text { conceptualization } \\
\text { of co-preneurship) }\end{array}$ \\
\hline $\begin{array}{l}\text { Graves \& } \\
\text { Thomas } \\
(2008)\end{array}$ & $\begin{array}{l}\text { What are the key } \\
\text { determinants that } \\
\text { influence the } \\
\text { pathways to } \\
\text { internationalization } \\
\text { taken by small to } \\
\text { medium-sized } \\
\text { family enterprises } \\
\text { and in what ways } \\
\text { does the family unit } \\
\text { influence these } \\
\text { determinants? }\end{array}$ & $\begin{array}{l}\text { Internationalization } \\
\text { in family firms. }\end{array}$ & $\begin{array}{l}\text { Eight internationally-active } \\
\text { Australian small and medium } \\
\text { family enterprises from } \\
\text { manufacturing industries. }\end{array}$ & $\begin{array}{l}\text { Multiple case } \\
\text { study. }\end{array}$ & $\begin{array}{l}\text { Theory } \\
\text { building - } \\
\text { Exploratory } \\
\text { (need for } \\
\text { understanding } \\
\text { HOW) }\end{array}$ & $\begin{array}{l}\text { Multiple direct interviews } \\
\text { ( } 34 \text { interviews with senior } \\
\text { managers in each firm) } \\
\text { Observations } \\
\text { Notes from field visits } \\
\text { Questionnaires, Firm } \\
\text { documents and other archival } \\
\text { records }\end{array}$ & $\begin{array}{l}\text { NVivo software was employed } \\
\text { to store and manage data, } \\
\text { particularly to link data with } \\
\text { emerging concepts and themes, } \\
\text { exploring linkages between } \\
\text { concepts within each case, } \\
\text { across cases, and in developing } \\
\text { the overall conclusions }\end{array}$ & $\begin{array}{l}\text { Quotes } \\
\text { Tables } \\
\text { Figures/ } \\
\text { frameworks }\end{array}$ & 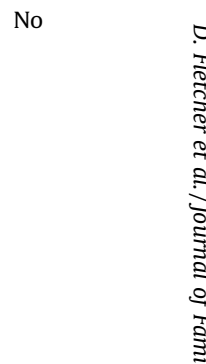 \\
\hline $\begin{array}{l}\text { Hall \& } \\
\text { Nordqvist } \\
\text { (2008) }\end{array}$ & $\begin{array}{l}\text { How can } \\
\text { professional } \\
\text { management in } \\
\text { family businesses be } \\
\text { understood by } \\
\text { explicitly } \\
\text { recognizing the } \\
\text { unique } \\
\text { characteristics of } \\
\text { these firms, } \\
\text { originating in the } \\
\text { influence of family } \\
\text { on the business? }\end{array}$ & $\begin{array}{l}\text { Professional } \\
\text { management in } \\
\text { family business. }\end{array}$ & Five Swedish family firms. & $\begin{array}{l}\text { Multiple case } \\
\text { study. }\end{array}$ & $\begin{array}{l}\text { Theory } \\
\text { building - } \\
\text { Exploratory } \\
\text { (need for } \\
\text { understanding } \\
\text { HOW) }\end{array}$ & $\begin{array}{l}\text { Multiple direct interviews } \\
\text { (with CEOs, former CEOs, top } \\
\text { managers, and board members) } \\
\text { Observation of meetings } \\
\text { Informal interactions with } \\
\text { family and firm-related } \\
\text { individuals during site visits }\end{array}$ & $\begin{array}{l}\text { Reading and successive } \\
\text { interpretation of transcribed } \\
\text { interviews and observation } \\
\text { notes, grouping into empirical } \\
\text { categories of the patterns of } \\
\text { reoccurring aspects in the } \\
\text { cases, clustering of these } \\
\text { categories into themes and final } \\
\text { reinterpretation of the cases }\end{array}$ & Quotes & $\begin{array}{l}\text { No (the authors } \\
\text { formalize a } \\
\text { definition of } \\
\text { professional } \\
\text { management in } \\
\text { the family firm) }\end{array}$ \\
\hline $\begin{array}{l}\text { Hall, Melin, } \\
\text { \& } \\
\text { Nordqvist } \\
(2001)\end{array}$ & Not specified. & $\begin{array}{l}\text { The relationship } \\
\text { between } \\
\text { organizational } \\
\text { culture and the } \\
\text { entrepreneurial } \\
\text { process in family } \\
\text { firms. }\end{array}$ & $\begin{array}{l}\text { Two longitudinal and in-depth } \\
\text { case studies of medium-sized } \\
\text { Swedish family firms operating } \\
\text { in the manufacturing } \\
\text { industries. Both family } \\
\text { businesses faced radical } \\
\text { strategic change during the } \\
\text { three years before the study } \\
\text { and had strong business } \\
\text { cultures influenced by family } \\
\text { members. }\end{array}$ & $\begin{array}{l}\text { Multiple case } \\
\text { study. }\end{array}$ & $\begin{array}{l}\text { Theory } \\
\text { building - } \\
\text { Exploratory } \\
\text { (need for } \\
\text { understanding } \\
\text { HOW) }\end{array}$ & $\begin{array}{l}\text { Multiple direct interviews } \\
\text { Participant and nonparticipant } \\
\text { observations } \\
\text { Documents }\end{array}$ & Not explicitly specified & $\begin{array}{l}\text { Quotes } \\
\text { Figures/ } \\
\text { frameworks }\end{array}$ & No \\
\hline
\end{tabular}




\begin{tabular}{|c|c|c|c|c|c|c|c|c|c|c|}
\hline Study & Research question & Study subject & Site selection & $\begin{array}{l}\text { Qualitative } \\
\text { method chosen }\end{array}$ & $\begin{array}{l}\text { Theoretical } \\
\text { purpose and } \\
\text { rationale }\end{array}$ & Source of data collection & Analysis \& interpretation & $\begin{array}{l}\text { Presentation } \\
\text { of results }\end{array}$ & $\begin{array}{l}\text { Development of } \\
\text { propositions }\end{array}$ & \\
\hline $\begin{array}{l}\text { Howorth, } \\
\text { Westhead } \\
\text { \& Wright } \\
(2004)\end{array}$ & $\begin{array}{l}\text { What impact do } \\
\text { information } \\
\text { asymmetries have on } \\
\text { the ownership } \\
\text { transfer process } \\
\text { when an MBO or MBI } \\
\text { team acquires a } \\
\text { private family firm? } \\
\text { Which aspects of the } \\
\text { ownership transfer } \\
\text { process impact } \\
\text { satisfaction with the } \\
\text { outcome for the } \\
\text { vendor and MBO or } \\
\text { MBI team? Which } \\
\text { aspects of the } \\
\text { ownership transfer } \\
\text { process impact the } \\
\text { knowledge transfer } \\
\text { between former } \\
\text { family owners and } \\
\text { the MBO or MBI } \\
\text { team? }\end{array}$ & $\begin{array}{l}\text { Succession issues of } \\
\text { family firms who } \\
\text { have selected a } \\
\text { Management Buy- } \\
\text { out (MBO)/ } \\
\text { Management Buy-in } \\
\text { (MBI). }\end{array}$ & $\begin{array}{l}\text { Multiple case studies involving } \\
\text { eight privately-held family } \\
\text { firms in the UK. The average } \\
\text { firm had } 109 \text { employees and } \\
\text { was } 34 \text { years old. The sample } \\
\text { was drawn from the Centre for } \\
\text { Management Buyout Research } \\
\text { database. }\end{array}$ & $\begin{array}{l}\text { Multiple case } \\
\text { study. }\end{array}$ & $\begin{array}{l}\text { Theory } \\
\text { building - } \\
\text { Exploratory } \\
\text { and } \\
\text { explanatory } \\
\text { (need for } \\
\text { understanding } \\
\text { HOW and } \\
\text { WHY) }\end{array}$ & $\begin{array}{l}\text { Direct interviews (multiple- } \\
\text { respondent interviews with } \\
\text { former family owners and } \\
\text { current members of the MBO/ } \\
\text { MBI } \\
\text { Teams). }\end{array}$ & Not explicitly specified & $\begin{array}{l}\text { Quotes } \\
\text { Tables } \\
\text { Figures/ } \\
\text { frameworks }\end{array}$ & YES & 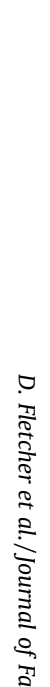 \\
\hline $\begin{array}{l}\text { Irava \& } \\
\text { Moore } \\
(2010)\end{array}$ & Not specified. & $\begin{array}{l}\text { Familiness and the } \\
\text { unique resources of } \\
\text { family firms. }\end{array}$ & $\begin{array}{l}\text { Four family-owned businesses } \\
\text { ranging in size from } 15 \text { to more } \\
\text { than } 800 \text { employees and } \\
\text { belonging to four different } \\
\text { industries. All four firms were } \\
\text { of Australian heritage, } \\
\text { multigenerational, private } \\
\text { firms with } 100 \% \text { family } \\
\text { ownership, and had shown } \\
\text { significant growth since their } \\
\text { establishment. }\end{array}$ & $\begin{array}{l}\text { Multiple case } \\
\text { study. }\end{array}$ & $\begin{array}{l}\text { Theory } \\
\text { building - } \\
\text { Exploratory } \\
\text { (need for } \\
\text { understanding } \\
\text { HOW) }\end{array}$ & $\begin{array}{l}\text { Multiple direct interviews } \\
\text { ( } 16 \text { open-ended, semi- } \\
\text { structured interviews } \\
\text { Observations } \\
\text { Secondary sources } \\
\text { (correspondence, documents } \\
\text { and company published } \\
\text { material) }\end{array}$ & $\begin{array}{l}\text { Within-case analysis (using } \\
\text { techniques such as } \\
\text { constructing } \\
\text { information arrays, matrix of } \\
\text { categories, creating flowcharts, } \\
\text { and data displays); } \\
\text { Cross-case analysis; } \\
\text { NVivo software used for coding } \\
\text { and for exploring patterns } \\
\text { across cases }\end{array}$ & $\begin{array}{l}\text { Quotes } \\
\text { Tables } \\
\text { Figures/ } \\
\text { frameworks }\end{array}$ & No & 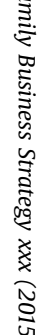 \\
\hline $\begin{array}{l}\text { Johannisson } \\
\text { \& Huse } \\
\text { (2000) }\end{array}$ & $\begin{array}{l}\text { How do different } \\
\text { ideologies in the } \\
\text { small family } \\
\text { business influence } \\
\text { the selection of } \\
\text { outside directors? }\end{array}$ & $\begin{array}{l}\text { The appointment of } \\
\text { outside board } \\
\text { members in family } \\
\text { businesses. }\end{array}$ & $\begin{array}{l}\text { Twelve Swedish privately-held } \\
\text { small family businesses and a } \\
\text { longitudinal, in-depth case } \\
\text { study of two family businesses } \\
\text { (one traditional and one } \\
\text { entrepreneurial). }\end{array}$ & $\begin{array}{l}\text { Multiple case } \\
\text { study. }\end{array}$ & $\begin{array}{l}\text { Theory } \\
\text { building - } \\
\text { Exploratory } \\
\text { (need for } \\
\text { understanding } \\
\text { HOW) }\end{array}$ & $\begin{array}{l}\text { Multiple direct interviews } \\
\text { (with CEOs, family members, } \\
\text { firm partners, and external } \\
\text { board members) }\end{array}$ & Not explicitly specified & $\begin{array}{l}\text { Quotes } \\
\text { Tables }\end{array}$ & No & $\begin{array}{l}\sqrt{x} \\
x \\
x \\
x \\
x \\
x \\
x \\
x\end{array}$ \\
\hline $\begin{array}{l}\text { Karra, } \\
\text { Tracey, \& } \\
\text { Phillips } \\
(2006)\end{array}$ & $\begin{array}{l}\text { What is the } \\
\text { relationship } \\
\text { between altruism } \\
\text { and agency costs in } \\
\text { family businesses? } \\
\text { Does this } \\
\text { relationship vary } \\
\text { over time? }\end{array}$ & $\begin{array}{l}\text { The role of altruism } \\
\text { over time in } \\
\text { explaining a } \\
\text { growing family } \\
\text { firm's agency costs. }\end{array}$ & $\begin{array}{l}\text { Neroli, a successful } \\
\text { international family business } \\
\text { founded in Turkey. The authors } \\
\text { studied the period of rapid } \\
\text { growth experienced by the firm } \\
\text { since the late } 1990 \text { s. During this } \\
\text { period, Neroli successfully } \\
\text { penetrated markets across } \\
\text { Eastern Europe. By the end of } \\
\text { the study, the firm employed } \\
\text { about } 750 \text { people and had } \\
87 \text { retail outlets across the } \\
\text { former Soviet republics and } \\
\text { Eastern Europe. }\end{array}$ & $\begin{array}{l}\text { Single case } \\
\text { study. }\end{array}$ & $\begin{array}{l}\text { Theory } \\
\text { building - } \\
\text { Descriptive }\end{array}$ & $\begin{array}{l}\text { Direct and telephone } \\
\text { interviews (with key members } \\
\text { of the firm and its partners) } \\
\text { Archival data }\end{array}$ & $\begin{array}{l}\text { I stage: Organization of case } \\
\text { data into an "event history } \\
\text { database" } \\
\text { by chronologically ordering } \\
\text { descriptions of events taken } \\
\text { from the raw data-interview } \\
\text { transcripts, interview and field } \\
\text { notes, and secondary sources } \\
\text {-and by juxtaposing multiple } \\
\text { accounts against each } \\
\text { other to ascertain the degree of } \\
\text { convergence. This allowed the } \\
\text { development of a narrative. } \\
\text { II stage: documenting and } \\
\text { tracking the emerged evidence, }\end{array}$ & Quotes & No & \\
\hline
\end{tabular}




\begin{tabular}{|c|c|c|c|c|}
\hline $\begin{array}{l}\text { Kotlar, \& De } \\
\text { Massis } \\
(2013)\end{array}$ & $\begin{array}{l}\text { Central research } \\
\text { question: How do the } \\
\text { individual goals of } \\
\text { organizational } \\
\text { members influence } \\
\text { the organizational } \\
\text { goals pursued by } \\
\text { family firms? } \\
\text { Theory questions: } \\
\text { What goals do } \\
\text { family firm } \\
\text { organizational } \\
\text { members pursue? } \\
\text { How do such goals } \\
\text { relate to the } \\
\text { individual } \\
\text { characteristics of the } \\
\text { informants? How do } \\
\text { these relationships } \\
\text { change across family } \\
\text { firms? How do the } \\
\text { individual goals of } \\
\text { family firm } \\
\text { organizational } \\
\text { members affect the } \\
\text { decision-making } \\
\text { processes in family } \\
\text { firms? }\end{array}$ & $\begin{array}{l}\text { Goal setting } \\
\text { processes in family } \\
\text { firms. }\end{array}$ & $\begin{array}{l}76 \text { organizational members } \\
\text { across } 19 \text { Italian small and } \\
\text { medium family firms operating } \\
\text { in different industries. }\end{array}$ & $\begin{array}{l}\text { Theory- } \\
\text { building } \\
\text { qualitative } \\
\text { study based on } \\
\text { interviews and } \\
\text { observations } \\
\text { data. }\end{array}$ \\
\hline $\begin{array}{l}\text { Lambrecht } \\
\text { (2005) }\end{array}$ & $\begin{array}{l}\text { How is it that one } \\
\text { family succeeds } \\
\text { in passing the } \\
\text { business down to } \\
\text { following } \\
\text { generations while } \\
\text { another family fails? }\end{array}$ & $\begin{array}{l}\text { Succession and } \\
\text { succession planning } \\
\text { in family firms. }\end{array}$ & $\begin{array}{l}\text { Multiple case studies involving } \\
\text { eight family firms. The cases } \\
\text { were chosen from scientific and } \\
\text { popular articles. }\end{array}$ & $\begin{array}{l}\text { Multiple case } \\
\text { study. }\end{array}$ \\
\hline $\begin{array}{l}\text { Miller, } \\
\text { Steier, \& Le } \\
\text { Breton- } \\
\text { Miller } \\
\text { (2003) }\end{array}$ & $\begin{array}{l}\text { What are the core } \\
\text { problems and their } \\
\text { organizational } \\
\text { implications in } \\
\text { failing } \\
\text { intergenerational } \\
\text { successions? }\end{array}$ & $\begin{array}{l}\text { Problems and } \\
\text { common patterns in } \\
\text { failing } \\
\text { intergenerational } \\
\text { successions. }\end{array}$ & $\begin{array}{l}\text { Multiple case studies involving } \\
16 \text { family-owned businesses } \\
\text { where a succession process } \\
\text { failed (either successor } \\
\text { dismissal or bankruptcy). }\end{array}$ & $\begin{array}{l}\text { Multiple case } \\
\text { study. }\end{array}$ \\
\hline $\begin{array}{l}\text { Murray } \\
(2003)\end{array}$ & $\begin{array}{l}\text { What determines } \\
\text { whether a } \\
\text { generational } \\
\text { transition happens } \\
\text { as a relatively } \\
\text { smooth process or as } \\
\text { a revolutionary } \\
\text { change? }\end{array}$ & $\begin{array}{l}\text { The succession } \\
\text { transition process. }\end{array}$ & $\begin{array}{l}\text { Drawing from the } 1994 \text { survey } \\
\text { of Scotland and Northern } \\
\text { Ireland's family enterprises, the } \\
\text { authors selected five firms that } \\
\text { had achieved at least } 5 \text { percent } \\
\text { per year increase in sales over a } \\
5 \text {-year period prior to the } \\
\text { analysis and that agree that } \\
\text { succession will occur within } \\
\text { the next } 5 \text { years. }\end{array}$ & $\begin{array}{l}\text { Multiple case } \\
\text { study. }\end{array}$ \\
\hline
\end{tabular}

and moving back and forth

between data and theory until

theoretical saturation

The two authors independently Quotes Yes (the authors

understanding with CEOs, professional

ead interviews, observations and archival data; nonfamily top executives, young generation family NVivo software used for framework

7 propositions)

members, family CEO spouses, Iteratively analysis of the and old generation family qualitative data by moving back and forth between the data and Observation duing family and an emerging structure of business meetings theoretical arguments that (e.g., meetings of the board of responded to the theory directors, family meetings, and questions, according to three casual meetings) key steps: (i) creating

Secondary sources (contracts, provisional categories and firsthistorical books about the order codes; (ii) integrating organization and the family, first-order codes and creating corporate websites, news second-order

articles about the firm and the Themes; and (iii) delimiting the family, and firm pamphlets)

theory by aggregating theoretical dimensions
Theory building Explanatory (need for understandin WHY)

Theory building Exploratory (need for understanding HOW

Theory building Explanatory (need for understanding WHY)

g

\section{Direct interviews}

(19 interviews with multiple members of the current and future generation of family Biographies of business families

Observations

Popular articles

Scientific articles

Case and historical book

accounts, as well as

newspapers and journal

articles on the strategy and

organization of the 16 and

during the $5-10$ years following succession

Direct interviews (with the key Collation of primary and individuals, dyads and families secondary information to between 1994 and 1999) create a narrative account Secondary data (company (comparative case study
(comatrative account accounts, consultants' reports, method); analysis of the media coverage and marketing narratives as well as the material) plotting of individual shights, an owners and managers) constituents, their families and their businesses along a time
Not specified (four researchers Figures/

frameworks

No to give feedback to interim reports and multiple sources information)

Two raters read materials on each firm and performed a double-blind scoring of the variables and symptoms

Quotes

The authors developed

hypotheses rather than propositions. 
Table 2 (Continued)

\begin{tabular}{|c|c|c|c|c|c|c|c|c|c|c|}
\hline Study & Research question & Study subject & Site selection & $\begin{array}{l}\text { Qualitative } \\
\text { method chosen }\end{array}$ & $\begin{array}{l}\text { Theoretical } \\
\text { purpose and } \\
\text { rationale }\end{array}$ & Source of data collection & Analysis \& interpretation & $\begin{array}{l}\text { Presentation } \\
\text { of results }\end{array}$ & $\begin{array}{l}\text { Development of } \\
\text { propositions }\end{array}$ & \\
\hline $\begin{array}{l}\text { Nordqvist \& } \\
\text { Melin } \\
(2010)\end{array}$ & Not specified. & $\begin{array}{l}\text { Strategic planning in } \\
\text { family business. }\end{array}$ & $\begin{array}{l}\text { Three medium-sized } \\
\text { and multigenerational family } \\
\text { firms. }\end{array}$ & $\begin{array}{l}\text { Multiple case } \\
\text { study. }\end{array}$ & $\begin{array}{l}\text { Theory } \\
\text { building - } \\
\text { Exploratory } \\
\text { (need for } \\
\text { understanding } \\
\text { HOW) }\end{array}$ & $\begin{array}{l}\text { Multiple direct interviews ( } 98 \\
\text { interviews with key-actors, } \\
\text { such as owners, managers, } \\
\text { consultants, board members, } \\
\text { family members, accountants, } \\
\text { former managers) } \\
\text { Observations of } 10 \text { meetings } \\
\text { where strategic issues were } \\
\text { treated (board meetings, top } \\
\text { management team meetings, } \\
\text { strategic planning meetings, } \\
\text { strategy away days) } \\
\text { Casual conversations } \\
\text { Site visits } \\
\text { Secondary sources }\end{array}$ & $\begin{array}{l}\text { Writing of detailed and } \\
\text { process-oriented case } \\
\text { descriptions; } \\
\text { Reinterpretation of the } \\
\text { empirical material with focus } \\
\text { on the character and meaning } \\
\text { of the strategic planning } \\
\text { processes; } \\
\text { Iterative moving back and fort } \\
\text { from data and literature to } \\
\text { support emerging theory } \\
\text { generation and refinement }\end{array}$ & $\begin{array}{l}\text { Quotes } \\
\text { Tables }\end{array}$ & No & ד. \\
\hline $\begin{array}{l}\text { Parada, } \\
\text { Nordqvist, } \\
\text { \& Gimeno } \\
(2010)\end{array}$ & Not specified. & $\begin{array}{l}\text { Professional } \\
\text { associations and } \\
\text { change of family } \\
\text { values. }\end{array}$ & $\begin{array}{l}\text { Three Spanish family firms } \\
\text { operating in three different } \\
\text { industries (Pharmaceuticals, } \\
\text { Tourism and Construction and } \\
\text { energy). }\end{array}$ & $\begin{array}{l}\text { Multiple case } \\
\text { study. }\end{array}$ & $\begin{array}{l}\text { Theory } \\
\text { building - } \\
\text { Exploratory } \\
\text { (need for } \\
\text { understanding } \\
\text { HOW) }\end{array}$ & $\begin{array}{l}\text { Multiple direct interviews } \\
\text { (with } 22 \text { family and nonfamily } \\
\text { members) } \\
\text { Secondary data (newspapers, } \\
\text { corporate brochures, Internet } \\
\text { information, annual reports, } \\
\text { organizational charts and } \\
\text { family constitutions) }\end{array}$ & $\begin{array}{l}\text { Within-case analysis; } \\
\text { Cross-case analysis; } \\
\text { Iterative process during which } \\
\text { the researchers went back and } \\
\text { forth between the data } \\
\text { collected and their initial } \\
\text { institutional theory framework, } \\
\text { in an "abductive" manner }\end{array}$ & $\begin{array}{l}\text { Quotes } \\
\text { Tables } \\
\text { Figures/ } \\
\text { frameworks }\end{array}$ & No & 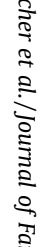 \\
\hline $\begin{array}{l}\text { Salvato, } \\
\text { Chirico, \& } \\
\text { Sharma } \\
(2010)\end{array}$ & $\begin{array}{l}\text { What factors } \\
\text { influence exit from } \\
\text { the founder's } \\
\text { business and } \\
\text { subsequent entry } \\
\text { into a growing } \\
\text { industry, while } \\
\text { retaining family } \\
\text { control? }\end{array}$ & $\begin{array}{l}\text { Entrepreneurship } \\
\text { and firm renewal } \\
\text { across generations } \\
\text { in family firms. }\end{array}$ & $\begin{array}{l}\text { The authors traced the } \\
\text { development of the Italian } \\
\text { Falck Group from its inception } \\
\text { as a steel company in 1906, its } \\
\text { ascension as the largest } \\
\text { privately-owned steel producer } \\
\text { in Italy, its losses in the 1970s } \\
\text { and 1980s leading to business } \\
\text { exit from the steel industry in } \\
\text { the } 1990 \text { s, and its successful } \\
\text { entry into the renewable } \\
\text { energy business. }\end{array}$ & $\begin{array}{l}\text { Single case } \\
\text { study. }\end{array}$ & $\begin{array}{l}\text { Theory } \\
\text { building - } \\
\text { Exploratory } \\
\text { (need for } \\
\text { understanding } \\
\text { HOW) }\end{array}$ & $\begin{array}{l}\text { Multiple direct interviews } \\
\text { (semi-structured, with family } \\
\text { and nonfamily } \\
\text { members who were directly } \\
\text { involved in the exit and renewal } \\
\text { process) } \\
\text { Secondary sources (company } \\
\text { websites, financial reports, } \\
\text { magazines and newspaper } \\
\text { articles, transcripts of the board } \\
\text { of director meetings, research } \\
\text { reports and books) }\end{array}$ & $\begin{array}{l}\text { Inductive analysis of primary } \\
\text { and secondary data by using } \\
\text { techniques for the constant } \\
\text { comparison of data and } \\
\text { emerging data structure. } \\
\text { QSR-N6 software used to } \\
\text { manage and analyse empirical } \\
\text { evidence. } \\
\text { Techniques for open and axial } \\
\text { coding used for data analysis. }\end{array}$ & $\begin{array}{l}\text { Quotes } \\
\text { Figures/ } \\
\text { frameworks }\end{array}$ & No & 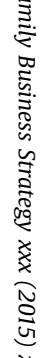 \\
\hline $\begin{array}{l}\text { Steier } \\
\text { (2001a) }\end{array}$ & Not specified. & $\begin{array}{l}\text { The dynamics of } \\
\text { trust and its } \\
\text { relationship to } \\
\text { organizational } \\
\text { governance within } \\
\text { the family firm. }\end{array}$ & $\begin{array}{l}\text { Three case studies based on } \\
\text { qualitative data gathered via } \\
\text { personal interviews, and library } \\
\text { and internet-based research. } \\
\text { All cases are well-established } \\
\text { companies, making family } \\
\text { dynamics in relation to } \\
\text { company performance well } \\
\text { observable. }\end{array}$ & $\begin{array}{l}\text { Multiple case } \\
\text { study. }\end{array}$ & $\begin{array}{l}\text { Theory } \\
\text { building - } \\
\text { Exploratory } \\
\text { (need for } \\
\text { understanding } \\
\text { HOW) }\end{array}$ & $\begin{array}{l}\text { Direct interviews } \\
\text { Site visits } \\
\text { Library and Internet-based } \\
\text { research }\end{array}$ & $\begin{array}{l}\text { The author says: "The study } \\
\text { followed procedures } \\
\text { commonly recommended } \\
\text { for conducting case study } \\
\text { research" (p.357) }\end{array}$ & $\begin{array}{l}\text { Case } \\
\text { vignettes }\end{array}$ & Yes & 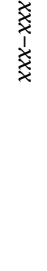 \\
\hline $\begin{array}{l}\text { Steier } \\
\text { (2001b) }\end{array}$ & $\begin{array}{l}\text { How can critical } \\
\text { relationships } \\
\text { realistically be } \\
\text { managed during } \\
\text { succession? }\end{array}$ & $\begin{array}{l}\text { Management of } \\
\text { social capital during } \\
\text { generational } \\
\text { transitions. }\end{array}$ & $\begin{array}{l}\text { Eighteen next-generation } \\
\text { entrepreneurs who inherited } \\
\text { business assets from a previous } \\
\text { generation. Firms are } \\
\text { heterogeneous in terms of } \\
\text { industry and size. }\end{array}$ & $\begin{array}{l}\text { Qualitative } \\
\text { study based on } \\
\text { interviews (not } \\
\text { specified } \\
\text { whether it is a } \\
\text { case study). }\end{array}$ & $\begin{array}{l}\text { Theory } \\
\text { building - } \\
\text { Exploratory } \\
\text { (need for } \\
\text { understanding } \\
\text { HOW) }\end{array}$ & $\begin{array}{l}\text { Multiple direct interviews } \\
\text { Information obtained from } \\
\text { Ernst \& Young reports, annual } \\
\text { reports, and company } \\
\text { publications }\end{array}$ & $\begin{array}{l}\text { Open coding, category } \\
\text { formation and theoretical } \\
\text { coding }\end{array}$ & $\begin{array}{l}\text { Quotes } \\
\text { Figures/ } \\
\text { frameworks }\end{array}$ & Yes & \\
\hline
\end{tabular}




\begin{tabular}{|c|c|c|c|c|c|c|c|c|c|}
\hline $\begin{array}{l}\text { Steier \& } \\
\text { Miller } \\
(2010)\end{array}$ & $\begin{array}{l}\text { How do family firms } \\
\text { transition from one } \\
\text { generation to the } \\
\text { next? What is the } \\
\text { impact of next } \\
\text { generation } \\
\text { managers in this } \\
\text { transition? Over } \\
\text { time, what roles do } \\
\text { family members } \\
\text { play in the } \\
\text { management, } \\
\text { ownership and } \\
\text { control of their } \\
\text { business? What are } \\
\text { the "rationalities" or } \\
\text { "drivers" of their } \\
\text { decision making } \\
\text { before and after } \\
\text { succession? }\end{array}$ & $\begin{array}{l}\text { Change in family } \\
\text { business governance } \\
\text { of entrepreneurial } \\
\text { family firms before, } \\
\text { during, and after } \\
\text { succession. }\end{array}$ & $\begin{array}{l}\text { Thirteen second or later } \\
\text { generation CEOs of } \\
\text { entrepreneurial family firms } \\
\text { (entrepreneurial family firms } \\
\text { defined as firms that had } \\
\text { created something new and } \\
\text { innovative and/or were growth } \\
\text { oriented). }\end{array}$ & $\begin{array}{l}\text { Multiple case } \\
\text { study. }\end{array}$ & $\begin{array}{l}\text { Theory } \\
\text { building - } \\
\text { Exploratory } \\
\text { (need for } \\
\text { understanding } \\
\text { HOW) }\end{array}$ & $\begin{array}{l}\text { Multiple direct interviews } \\
\text { (three interviews with each of } \\
\text { the CEOs of the family firms) } \\
\text { Secondary sources (websites, } \\
\text { annual reports, print material } \\
\text { and news clipping) }\end{array}$ & $\begin{array}{l}\text { Prior to } \\
\text { interviews, secondary sources } \\
\text { of data were analyzed to } \\
\text { determine } \\
\text { key events in the history of the } \\
\text { firm; } \\
\text { The authors say that they } \\
\text { "followed procedures } \\
\text { commonly recommended } \\
\text { for developing grounded theory } \\
\text { from case study research" } \\
\text { (p.146); } \\
\text { Both authors read and re-read } \\
\text { the transcripts to discern } \\
\text { emerging themes and patterns; } \\
\text { To establish the robustness of } \\
\text { the themes and tendencies } \\
\text { being observed, they split the } \\
\text { interview data } \\
\text { into two random samples; } \\
\text { The authors recruited a } \\
\text { research assistant to read the } \\
\text { secondary source materials and } \\
\text { the interview transcripts to } \\
\text { identify which changes, as well } \\
\text { as which family priority and } \\
\text { themes, were exhibited by } \\
\text { which companies, and when }\end{array}$ & $\begin{array}{l}\text { Quotes } \\
\text { Tables }\end{array}$ & Yes \\
\hline $\begin{array}{l}\text { Tsang } \\
\text { (2002) }\end{array}$ & $\begin{array}{l}\text { What are the } \\
\text { differences in } \\
\text { foreign direct } \\
\text { investment } \\
\text { behaviors of the } \\
\text { Chinese family and } \\
\text { non-family } \\
\text { businesses? }\end{array}$ & $\begin{array}{l}\text { Foreign direct } \\
\text { investment (FDI) } \\
\text { behavior of Chinese } \\
\text { family businesses. }\end{array}$ & $\begin{array}{l}\text { Multiple case studies involving } \\
\text { ten private Chinese firms } \\
\text { operating in manufacturing } \\
\text { industries in Singapore (three } \\
\text { family, three semi-family, and } \\
\text { four non-family businesses). } \\
\text { The average firm had } \\
410 \text { employees in Singapore } \\
\text { and } 12500 \text { worldwide. }\end{array}$ & $\begin{array}{l}\text { Multiple case } \\
\text { study. }\end{array}$ & $\begin{array}{l}\text { Theory } \\
\text { building - } \\
\text { Exploratory } \\
\text { (need for } \\
\text { understanding } \\
\text { HOW) }\end{array}$ & $\begin{array}{l}\text { Semi-structured interviews } \\
\text { (60 interviews with managers } \\
\text { in charge in the top } \\
\text { management teams of their } \\
\text { companies) }\end{array}$ & Not explicitly specified & Table & No \\
\hline $\begin{array}{l}\text { Vera \& Dean } \\
\text { (2005) }\end{array}$ & Not specified. & $\begin{array}{l}\text { The difficulties faced } \\
\text { by daughters taking } \\
\text { over the family } \\
\text { business. }\end{array}$ & $\begin{array}{l}\text { The study considered ten } \\
\text { daughters who had taken over } \\
\text { their family businesses. The } \\
\text { firms were all based in US, had } \\
\text { on average } 57 \text { employees, and } \\
\text { were } 38 \text { years old. }\end{array}$ & $\begin{array}{l}\text { Qualitative } \\
\text { study based on } \\
\text { interviews (not } \\
\text { specified } \\
\text { whether it is a } \\
\text { case study). }\end{array}$ & $\begin{array}{l}\text { Descriptive } \\
\text { (need for } \\
\text { examining the } \\
\text { issues } \\
\text { identified by } \\
\text { prior research } \\
\text { on women in } \\
\text { family business } \\
\text { in a sample of } \\
\text { female family } \\
\text { business } \\
\text { leaders) }\end{array}$ & $\begin{array}{l}\text { Direct structured interviews } \\
\text { (one-on-one interviews with } \\
\text { female family business owners) }\end{array}$ & $\begin{array}{l}\text { Interviews were transcribed } \\
\text { and data were analysed for } \\
\text { themes or patterns across } \\
\text { women's experiences. }\end{array}$ & $\begin{array}{l}\text { Quotes } \\
\text { Tables }\end{array}$ & No \\
\hline
\end{tabular}


business structures and behaviors and to promote the scholarship of micro-level research.

To address this, the first step in our analytical process is to review the kinds of research questions and topics being addressed through extant studies using qualitative methods. To aid this, some analytical tools drawn from Miles and Huberman (1994) are applied. This framework is useful as they outline a set of key primary threads that generally characterize the interests and distinctiveness of qualitative research practices. These threads are also consistent with later texts on the features, or what Bryman and Bell (2007) refer to as the 'preoccupations', of qualitative research. However, in order to avoid repetition and overlap between the key features of qualitative research, we have merged some of the threads outlined in the original formulation (i.e. we have given more attention to the ways in which qualitative research helps to generate theory than is explicitly addressed in the original list). These interests and preoccupations, as adapted from Miles and Huberman (1994, p.6-7) are outlined in column one of Table 1.

The five characteristics outlined in column 1 exemplify the key interests of qualitative research. In short, these incorporate the main reasons why researchers choose to approach their research in a qualitative way. For this reason, they are used as analytical categories for evaluating the sample of qualitative family business articles that comprises the empirical material for this study. In column 2, we also outline some of the distinctive features (strengths and limitations) of qualitative research applications that have been identified from the sample of selected articles and are discussed in more detail later in the article. The categories are helpful for addressing the objectives of this research which are to: (1) examine the range of questions being addressed in cited publications of family business articles using qualitative research; (2) assess why and how inquirers are engaging with these qualitative methods (i.e. what are they trying to get at and how they are conducting their inquiry); and (3) identify possible gaps in qualitative family business research conducted to date. In the following section, we discuss the analytical method adopted and explain the strength and limitations identified in column 2.

\section{Analytical method}

We utilize the bibliographical database and methodology adopted by De Massis, Sharma, Chua and Chrisman (2012) who, in their review of family business research from 1996 to 2010, identify 734 articles that have been particularly influential for the development of the field. From this, a sample of 215 articles that according to Google Scholar in February 2011 received at least five citations per year since publication, were categorized. Eighteen of these 215 articles had been classified by De Massis et al. (2012) as qualitative studies and were included in our sample.

We updated the Google Scholar citation search again in November 2013 where we checked the qualitative studies reported in the fresh review by Reay and Zhang (2014). This search yielded two additional articles with more than five citations per year (Chirico \& Nordqvist, 2010; Steier \& Miller, 2010). In addition, we also updated the search to include other articles published in 2010 with more than 10 total citations. This criterion yielded four additional articles (Fletcher, 2010; Irava \& Moores, 2010; Nordqvist \& Melin, 2010; Parada, Nordqvist, \& Gimeno, 2010) creating a subsample of 24 qualitative family business articles for the period 1996 to 2010. Finally, two further qualitative articles were added that were published in 2013 and which received at least 10 citations in Google Scholar by November 2013 (De Massis, Frattini, Pizzurno, \& Cassia, 2013; Kotlar \& De Massis, 2013). This brought the number of family business articles conducted with qualitative methodologies over a 15 -year period in eight academic journals ${ }^{2}$, to a total of $26^{3}$. This number is consistent with the number of articles included in other recent review articles in the family business field (e.g., De Massis, Frattini, Lichtenthaler, 2013).

In Table 2 we present the 26 qualitative studies according to several dimensions: research question, study subject, sample description, qualitative method chosen, theoretical purpose and rationale, role of theoretical concepts and theories (i.e. induced or deduced), data collection source, data analysis, presentation of results (i.e., quotations in text, figures or tables) and development of theoretical propositions.

We now discuss the articles presented in Table 2 with a view to discussing the range of interests pursued in family business research.

\section{Evaluation and analysis of family business studies using qualitative methods}

In what is to follow, we use the five sets of characteristics outlined earlier in column one of Table 1 to evaluate the kinds of research questions and topics being addressed in qualitative family business research. At the same time, at the end of each category we identify the gaps in extant family business qualitative research (these are also summarized in column two of Table 1 ).

\subsection{Qualitative research category (i):}

'Explicating the ways in which people in particular settings come to understand, account for, take action and otherwise manage their day-to-day situations'; 'suspending inquirer preconceptions in order to understand the accounts and intentions of local actors "from the inside" (Miles \& Huberman, 1994p. 6-7).

The key objective of qualitative research is to attempt to understand things from the point of view of the people being studied (Gubrium \& Holstein, 1997). This interest derives from the fact that in the social world it is social actors who attribute meaning either to inanimate objects around them in their environment, or experiences, events and practices. As a result, qualitative inquirers' efforts revolve around understanding the way in which social actors report their experiences, interactions and participation in the world (often in relation to contextual factors) (Denzin \& Lincoln, 1994).

The majority of reviewed studies are using qualitative methods to access the intentions/viewpoints/perspectives of individuals within the family firm. For example, referring to columns 2 and 3 of Table 2 (research questions and the key subjects being investigated) it can be noted that the motivations for qualitative studies and the subjects of the study vary. They range from an interest in the perspectives of particular social actors, for example nail shop owners (Bagwell, 2008); the experiences of women who report feeling invisible in family businesses (Cole, 1997); daughters during succession (Vera \& Dean, 2005) and the roles reported by couples in business (Fletcher, 2010), to the study of themes (i.e. executive succession (Dyck, Mauws, Starke, \& Mischke, 2002); the extension of family logic to relationships with non-family

\footnotetext{
2 We limited the review of the literature to influential articles published on established peer-reviewed journals as articles in academic journals can be regarded as validated knowledge and likely have a impact on the field (Ordanini, Rubera, \& DeFillippi, 2008; Podsakoff, Mackenzie, Bachrach, \& Podsakoff, 2005). Established influential journals are acknowledged to shape the research in a field by setting new horizons for investigation within their frame of reference (Furrer, Thomas, \& Goussevskaia, 2008). We therefore feel that this approach provides an accurate and representative picture of relevant scholarly research.

${ }^{3}$ It should be noticed that our review did not consider other potentially promising qualitative articles that have been recently published in Journal of Family Business Strategy but have not yet reached their potential in terms of number of citations (e.g., Camblanne, 2013; Hedberg \& Danes, 2012; Meier \& Schier, 2014; Murphy \& Lambrechts, 2015; Schlepphorst \& Moog, 2014; Welsh et al., 2013).
} 
members (Karra, Tracey, \& Phillips, 2006) and an interest in processes, relationships (i.e. how culture affects the relationship between knowledge and dynamic capabilities generations within the firm (Chirico \& Nordqvist, 2010 or the processes/critical relationships involved in generational transition (Murray, 2003; Steier, 2001b). Study of social interactions are also evident (i.e. the role of social interactions in shaping congruence between individual and organizational goals, Kotlar \& De Massis, 2013); factors influencing change in family-controlled organizations (Salvato, Chirico, \& Sharma (2010); trust building activities (Steier, 2001a); key events in the history of the firm (Steier \& Miller, 2010); cultural understandings involved in criteria for CEO selection (Hall \& Nordqvist, 2008) and aspirations/attitudes towards international risk taking (Graves \& Thomas, 2008).

In some of the reviewed studies, scholars pay attention to contextual factors and the situatedness of social actors (i.e. a local and situationalized understanding of the processes and roles of strategic planning, Nordqvist \& Melin, 2010). Another approach is to include and analyze the role of time and industrial context. One example is Salvato et al.'s (2010) longitudinal study of exit where a declining industry was an important reason for why the studied family business decided to leave their original industry (also, Murray, 2003). Another contextual factor related to time is the generation in charge of a family business. A few of the reviewed qualitative studies pay attention to inter-generational relations and dynamic, sometimes in combination with other contextual factors such as industry (e.g. Dyck et al., 2002), or ideology (Johannisson \& Huse, 2000).

In many cases the individual experiences recounted are reported as 'firm level' representations. These are often aggregated into case studies or vignettes (i.e. Howorth, Westhead, \& Wright, 2004; Irava \& Moore, 2010; Karra et al., 2006; Lambrecht, 2005; Miller, Steier, \& Le Breton-Miller, 2003; Chirico \& Nordqvist, 2010; Salvato, Chirico, \& Sharma, 2010; Steier, 2001a), although some case studies are drawn from grounded theory (Steier \& Miller, 2010; Tsang, 2002) or are process oriented (Nordqvist \& Melin, 2010). Aggregating the findings from the level of individuals to the firm or organizational level is understandable to the extent that it is necessary to capture 'apt illustrations' (Gluckman, 1961) at a particularized level in order to generalize analytically to the firm level. This does mean, however, that rather than exploring the daily lives and experiences of individual actors for their own sake, the outcomes of the research tend to reify single person accounts (rather than the social situation) in which the account is given. This can be noted in the reported findings of the articles where authors use interviews/observations to access the personal accounts of social actors but then reify these accounts as representations of firm level 'performance', 'culture', 'success', 'inertia', 'failure' or 'risk-taking'.

In part, this is an issue related to the level of analysis adopted where, as in the traditional case study approach described by Yin (1994) and Eisenhardt (1989), inquirers are directed to study firm and organizational processes as the 'sum' of the practices, relations, emotions and interactions of the social actors that comprise them. In general, therefore, with the exception of three studies in our sample where the authors privilege the individual level and personal experiences in their own right (e.g. Cole, 1997; Fletcher, 2010; Vera \& Dean, 2005), the use of in-depth approaches to understand the "daily life of actors 'from the inside' through a process of deep attentiveness or empathetic understanding" (Miles \& Huberman, 1994) is rare to see $^{4}$.

There is also an absence of studies that investigate at close hand the interactions and relational dynamics that occur in organizational life. Often reference is made to the study of dynamics and processes but there is sometimes a tendency to base these processes on what people report during a one-to-one basis interview, rather than observing/reporting how people behave during interactions, exchanges and conversations in the work place (i.e., whether formally in board rooms, or informally with other family or non-family members).

This leads us to draw three conclusions about the attention given to actions and understandings from the point of view of the reported accounts of individuals or groups of people (see column 2 , Table 1). First, there is insufficient detailed research consideration given to the daily life of social actors, whether this is in terms of how they account for making sense of their experiences working in family firms, their situated actions and the relationality of family dynamics, or more particularly in their interactions/conversations with others. Second, with one or two exceptions, contextual factors are taken for granted or seen as embedded in the insights reported by respondents within the extant studies. Moreover, there is an absence of detailed attention to how contextual factors shape findings. Third, there is much evidence of firm level aggregations and the reification of personal accounts as representations of organizational outcomes (mostly in the form of case studies) that is based on a limited amount of interview material. A risk of reification is that it can 'guide the analysis towards unequivocal, logical results and interpretations ... [rather than] ... striv[ing] for multiplicity, variation, [and] the demonstration of inconsistences and fragmentations' (Alvesson \& Sköldberg, 2000, p. 152).

\subsection{Qualitative research category (ii):}

To see things in context and 'gain a holistic overview of the context under study [and] to work out the logic, arrangement and structuring of relationships, patterns and rules (whether explicit or implicit) in relation to context (adapted from Miles \& Huberman, 1994, p. 6).

A key strength of qualitative research compared to quantitative approaches is that they offer the inquirer the possibility to build a holistic ${ }^{5}$ perspective of the phenomenon under study and to observe the development of a phenomenon over time. The purpose of holistic efforts is to avoid 'snap-shot' perspectives and to make it possible to link together multiple factors and levels of analysis. This is considered to be important given that inquirers now acknowledge that organizations 'move' more than they are still (Chia \& Tsouskas, 2003).

Reviewing the articles presented in Table 2, we observe that several studies report an initial ambition to be holistic and to account for more complexity than has previously been done in their respective area of study. This is evident in the articles using a mix of data collection techniques as well as in studies that adopt an explicitly processual or longitudinal approach (Murray, 2003; Nordqvist et al., 2009) or studies concerned with dynamic capabilities (Chirico \& Nordqvist, 2010). An exemplar illustration is the five-year, longitudinal, multiple case study analysis of five family enterprise systems undertaken by Murray (2003). In this study, she plots qualitative longitudinal data along a time line and illustrates the sequence of phases through which the family firms progress over time, providing specific figures to visualize three different types of succession journeys.

Another observation is that the predominant approach used in family business qualitative research is the case study. In our sample, we observe that no less than seventeen of the reviewed papers using a case study approach rely on data collection from

\footnotetext{
${ }^{4}$ A useful example of a study that examines in detail in-depth process of power, control, collusion etc. is Ainsworth and Cox (2003). However, having 4.7 citations per year as of Google Scholar in November 2013, this was slightly below the criteria adopted for the methodology of our study.

${ }^{5}$ We acknowledge our reviewer's comment that there is a tendency for the 'holistic' term to be overused and under-defined. It is used here to be internally consistent with the Miles \& Huberman's (1994) usage.
} 
multiple cases, ranging from two cases (e.g. Chirico \& Nordqvist, 2010) to twelve cases (Johannisson \& Huse, 2000). This is rich material for cross-case comparative purposes (especially because cases may also embed numerical data) but naturally, the more cases that are included in multiple case design, the more difficult it is to capture, interpret and understand the holistic nature of the phenomenon studied in each case. Further, the more cases the investigator adopts to investigate, the less likely it is to be able achieve an in-depth understanding of the role of context and process emergence over time.

In addition, a multi level approach also requires multiple sources of data to examine a phenomenon. This is important to report and triangulate the different opinions and intentions that stakeholders have towards individual and organizational goals, decisions and interests. It also signals the value of collecting fieldwork material from more than one respondent and from more than one data collection point in time. Referring to Table 2 and the column titled 'data collection', it is possible to observe many uses of multiple sources of data and efforts to capture a multi level view of organizational phenomena. Only 6/26 of the articles relied on one data collection method with four using only semi-structured interviews (Bagwell, 2008; Cole, 1997; Dyck, 2002; Howorth et al., 2004) and two based only on documentary or secondary data sources (DeAngelo \& DeAngelo, 2000; Miller et al., 2003). The rest cited using mixed data sources ranging from interviews, observations, company documents, informal family data, websites, magazines, balance sheets, field notes, questionnaires and archival records.

Furthermore, fifteen of the twenty-six articles report that they collect data through interviews and observations from multiple respondents (i.e. Chirico \& Nordqvist, 2010; De Massis, Frattini, \& Pizzurno et al., 2013; Graves \& Thomas, 2008; Hall \& Nordqvist, 2008; Howorth et al., 2004; Irava \& Moore, 2010; Karra et al., 2006; Kotlar and De Massis, 2013; Lambrecht, 2005; Murray, 2003; Nordqvist and Melin, 2010; Parada et al., (2010); Salvato et al., 2010; Steier, 2001b; Steier \& Miller, 2010). This means that they include multiple perspectives in the analysis of the phenomenon they study. In many of the articles, the author(s) also describe the interview guide covering questions regarding past events, current issues, and future ambitions. This is one way of avoiding a 'snap-shot' perspective and for gathering field work material at different points in time. Relatively few of the reviewed articles, however, report explicitly that the authors used a strategy of repeated interactions in the field. Examples of articles that include research designs with longitudinal or repeated interactions in the fieldwork setting are Murray (2003),Parada et al. (2010) and Salvato et al. (2010).

From this analysis we draw the conclusion that there is a strong use of case studies in family business research which indicates a concern for holistic perspectives of family business activities. There is also a recurring use of multiple sources of data to enrich and triangulate findings and some evidence of longitudinal studies (although this could be expanded to increase variation in what could be observed and in the capacities to notice' Stewart, 2014, p. 74). At the same time, however, there is a tendency within extant qualitative family business research to reduce complexity and dynamics to a set of simple causal relationships devoid of context. There is also a lack of the study of repeated interactions in fieldwork over time and, in the search for unequivocal results, there is an absence of consideration to acts of organizing (Weick, 1995) or process-relational modes of inquiry ( Chia \& Tsoukas, 2003; Wood, 2002) which emphasizes flux, change, movement and the contradictory/paradoxical nature of organizational life. These limitations are outlined in Table 1, column 2.

\subsection{Qualitative research category (iii):}

To elucidate the sense-making accounts, behaviors, interactions, relationship patterns and structures reported during fieldwork; and to 'maintain field work accounts in their original forms throughout the study' (adapted from Miles \& Huberman, 1994, p. 7).

Many types of qualitative research approaches are associated with the collection and analysis of verbal accounts, written texts, narratives, linguistic terms or metaphors, life histories and personal (or family) stories (see, for example, Dawson \& Hjorth, 2012). As noted above, qualitative research approaches are favored, therefore, if the purpose of scholarly inquiry is to collect data that accounts for or reports the way people experience and interpret their life and work situations. Rather than coding and analyzing with numerical data, therefore, inquirers collect words and texts that they integrate to re-construct accounts that offer a deep understanding of a particular phenomenon.

The way verbal texts and accounts are presented in a specific research paper can vary. In general, within the family business field authors have frequently emphasized narratives and storytelling (Dawson \& Hjorth, 2012; Hamilton, 2013; McCollom, 1992) including some of the early works on family firms that contained anecdotes or personal stories (Donnelley, 1964). Usually, however, inquirers 'honor' the perspective of the individual actors in the analysis of their empirical material by using direct quotes derived from the descriptions and interpretations that the actors present to the inquirer in the moment of data collection. This is an important first step in qualitative research. At the same time, however, it is important to ensure what Stewart (2014, p.73) refers to as 'veracity' (descriptive truth) to safeguard that the field work effort is performed in such a way that it reflects the perspectives and descriptions made by the informants. Most qualitative inquirers, therefore, record the interviews and transcribe them verbatim, plus they take notes to ensure that the empirical material they work with reflects what is actually expressed during interviews. Further, many inquirers review the transcripts with the informants to confirm that no misunderstandings have emerged during the data collection phase.

Turning to the sample, in Table 2, it is observed that 22/26 of the reviewed qualitative articles use direct quotations from the respondents to visualize and illustrate the empirical material that forms the base of the analysis. Salvato et al's (2010) article regarding exit and divestments uses direct quotations extensively whereas others, such as Steier (2001b), use them sparingly, sometimes embedded in case study vignettes (Steier, 2001a). As qualitative research material, by its very nature, is word intensive, inquirers sometimes organize and summarize the qualitative material into diagrams and tables (e.g., Lambrecht, 2005; Murray, 2003). In other cases, the use of direct quotations is presented in the form of diagrams (e.g., Dyck et al., 2002; Irava \& Moore, 2010; Steier, 2001b). This helps to reduce and display extensive amounts of data and to display connections between themes. For the qualitative articles not using direct quotations (Fletcher, 2010; Lambrecht, 2005; Murray, 2003; Tang, 2002), the qualitative material is synthesized into narratives or tables. This is applicable where the detail of what is said in the direct quotes is of secondary importance to the synthesis of the material to aid a new conceptualization or develop theoretical propositions.

There is also very little evidence of authors using direct quotations and other forms of qualitative data to expose and understand deeper symbolic meanings. With the exception of Cole's (1997) study on the use of gender discrimination behaviors as 'weapons' for gaining access to senior positions and Hall and Nordqvist's (2008) study of professional management, from the sample of published articles, relatively few studies use qualitative material for the intention of 
examining more critical issues related to power, subordination, asymmetrical relations.

The conclusion we draw from the analysis of the sample regarding this category of qualitative research is that the use of direct quotations from respondents to demonstrate veracity is rare. Also, linguistic phrases are often presented in research accounts without contextual explanation which means that the everyday understandings and sense-making comments become reduced to an objectified collection of words (see Table 1, column 2). This overlooks the importance of language in communicating, negotiating and constituting meaning. It also contradicts with the purpose of qualitative research which is not only to display the accounts given 'in context' but also to explain their underlying logics, patterns and structural influences. As a result, the opportunity to 'go deeper' in examining how the more subtle cultural, political or structural issues shape organizational practice and sometimes produce asymmetries of power and relationships, is not fully realized.

\subsection{Qualitative research category (iv):}

To acknowledge the role that the researcher has in the research process.

The inquirer's active role in generating the empirical material from the field and then using this material to build new insights and knowledge is a central characteristic of qualitative research. For this reason, many qualitative research designs allow for an active involvement of the inquirer (whether this is in the form of personal interviews-both open ended or semi-structured, ethnography, covert or participant observation, forms of action or collaborative research and the more remote reviewing of archival documents). Acknowledging the centrality of the inquirer(s) in qualitative research is important to ensure the faithful reporting (and veracity) of fieldwork material. It is also important for making explicit how/why the inquirer 'treats' the empirical material and infers the connections and interpretations that relate to the emerging theoretical framework and which go beyond the "raw accounts" provided by the informants. One way of doing this is to conduct the fieldwork analysis with the purpose of extracting higher order themes and concepts that demonstrate an increased level of interpretation and theoretical understanding. The articles in Table 2 differ with regards to how the authors have chosen to describe and motivate their choice of data analysis.

As noted above, most of the studies reviewed rely on a combination of multiple sources to collect fieldwork material, and all of these sources allow for the inquirer to be central to the generation of new knowledge and theory. However, not one of the studies in the sample reports in a reflexive way the role the inquirer has in interacting with fieldwork respondents. Nor does any study explicitly state the analytical trail that the inquirer takes from generating research questions, to undertaking field work to the analysis/coding/organization of that material. This is in spite of the fact that the majority of the qualitative investigations undertook their analysis using manual coding or analysis (for example, only five sets of authors expressively stated that they used some sort of computer software to support their categorization, analysis and extraction themes of the empirical material (i.e., Bagwell, 2008; Graves \& Thomas, 2008; Irava \& Moore, 2010; Kotlar \& De Massis, 2013; Salvato et al., 2010). Whether using computer software or not, it is important to be rigorous in reporting the development of the analytical process, as this is central to aiding theory development. Moreover, reporting and sharing of the emergent findings with the research informants does not seem to be common practice in family business research and there was no evidence of this in the sample of articles.

This leads us to the conclusion for this category that there is a lack of transparency and detailed discussion of the analytical trails shaping the process of qualitative research, especially the trail from the research questioning and data collection to analysis and theory development (see Table 1, column 2). This lack of transparency undermines the scholarship of qualitative research and its role in explaining or justifying theoretical contributions. At the same time, the lack of reflexivity on the role of the qualitative inquirer in gaining access to fieldwork, building rapport and undertaking analysis, also reduces the authenticity and veracity of the reported findings. These aspects are usually stripped out of traditional research in an effort to remove bias and achieve objectivity but when acknowledged as central to research they enhance the transparency and veracity of the research account.

\subsection{Qualitative research category (v):}

Theory development is iterative rather than sequential and it emerges from fieldwork material and analysis (iterative process). There is no one single truth or explanation, there are multiple possibilities. 'Many interpretations of this material are possible, but some are more compelling for theoretical reasons or on grounds of internal consistency' (adapted from Miles \& Huberman, 1994, p.7).

Most qualitative research approaches are either primarily inductive or abductive (Alvesson \& Sköldberg, 2000). This means that while the research process can be theoretically influenced from the outset, the purpose is rarely to test a theory. Rather, the purpose is most often to develop new theory or to critique, amend or extend theory. As seen in Table 2, all the reviewed articles are categorized as having the theoretical purpose of building theory. However, the way they do that differs between the studies, as does the way the different articles report the new theory. Several of the sampled studies summarize the new theory in a set of propositions (e.g., Dyck et al., 2002; Howorth et al., 2004), whilst others exhibit a framework or a model (e.g., Irava \& Moore, 2010; Salvato et al., 2010). In addition, new theory is sometimes presented in the form of new language and concepts (e.g. Bagwell, 2008; Johannisson \& Huse, 2000) or a new conceptualization (Fletcher, 2010). Each of these ways of reporting theory development are appropriate where authors are consistent and follow through the analytical trail in terms of research questions, data collection and data analysis methods. In most cases, authors seem to have been engaged in an iterative research process characterized by an interplay of theory and empirical material that eventually leads to the elaboration of new theory or concepts. In general, however, the description and re-construction of how this process occurred is lacking.

In terms of theory development, it is interesting to observe that a majority of the reviewed qualitative articles are driven by the purpose to 'explore' how specific processes unfold or the nature of a particular phenomenon (e.g., Bagwell, 2008; Miller et al., 2003). This is consistent with traditional conceptions of qualitative research which uphold the value for exploring, uncovering and probing. However, in spite of this commitment to using qualitative methods for exploration purposes, it is rare for authors to elaborate what it means to explore processes or a phenomenon. Many authors are using qualitative methods to attempt to go beyond the surface and expose that which is not normally seen. For example, some of the studies cite descriptive theory building as the main theoretical task (DeAngelo \& DeAngelo, 2000; Karra et al., 2006). This is important for illuminating and making transparent things, events or activities previously hidden (even though qualitative methods also offer more than description or illumination for exploratory purposes). In addition, as noted above, the lack of transparency on the whole analytical trail also weakens the ability of reviewers to assess what new theoretical insights are being claimed and to seek out diversity (Stewart, 2014, p.77 referring to Barth, 1999, p.82). 
A further characteristic of many of the published qualitative articles in Table 2 is that they include theoretical propositions to summarize the main findings. To be specific, eight of the reviewed articles offer propositions that formally state the relationships between a set of key variables in focus of the empirical study. For example, Steier and Miller (2010) in their study on pre- and postsuccession governance philosophies in thirteen entrepreneurial family firms, suggest several testable propositions that summarize their qualitative evidence. The use of theoretical propositions can be a convenient and helpful way to summarize the key results of the study and to provide guidance for future research. What is more, the use of propositions that inspire future confirmatory research allows for qualitative evidence to be used and extended into theory-testing research. Some caution is necessary however, when producing propositions that have the effect of reducing the complexity of social reality to a set of simple causal relationships that are devoid of context as this undermines the qualitative effort to understand phenomena as processually and contextually situated.

Finally, qualitative research is often associated with a scientific view that holds that there is no one single truth or explanation but that there are multiple possibilities to see and understand a particular process or phenomenon. Despite the importance of this feature of qualitative research, there is a tendency in the published articles to communicate the findings as if they represent a single truth or explanation. This is related to the tendency to aggregate complex, multiple phenomena into 'tidy' organizational outcomes associated with 'performance' or 'culture' or 'familiness'. This is understandable to some extent where researchers aim to trace organizational outcomes 'backwards' to variable phenomena but in so doing, this runs the risk of over-simplifying complexity and dynamics that are not only devoid of context but which also limit the potential for multiple (possibly alternative) perspectives/explanations.

A final point in terms of theory development is that the philosophical roots are seldom discussed. In the few papers where the philosophical underpinning is explicitly specified, they are rooted in the interpretivist tradition (Hall, Melin, \& Nordqvist, 2001; Hall \& Nordqvist, 2008; Nordqvist \& Melin, 2010; Parada et al., 2008) or in the constructivist tradition (Cole, 1997). This suggests a general lack of reflexivity about the assumptions underlying research choices.

The conclusion to be drawn from this fifth category is that the main weakness in existing theory development is the tendency to reduce complexity, paradox, contradiction and dynamics to a set of simple causal relationships devoid of context. Moreover, too much effort is attached to searching for a single truth or explanation (see Table 1, column 2). Also, a lack of consideration/examination of the philosophical traditions shaping the research questions undermines the potential to examine how qualitative research approaches are sometimes nuanced by particular theoretical orientations (whether realist, grounded, positivist, interpretivist, hermeneutic or social constructionist).

\section{Extending the potential of qualitative research practices in family business scholarship}

From the preceding analysis, we have noted the ways in which qualitative research approaches are being applied in family business research (including strengths and limitations and the kinds of issues being addressed). In this section, we respond to these limitations by arguing for more reflexivity and scrutiny of the foundational questions that we are trying to get at when we undertake qualitative research. In emphasizing the significance of foundational questions, we follow Patton (2002, p.80), who uses such questions as the basis for achieving more clarity about the different lineages of qualitative research. We also extend this point to argue that re-orientating our research towards the underlying foundational questions is important for developing understandings and theories that are well suited to family business settings (Stewart, 2014, p.67).

In Table 3 , therefore, we outline a number of foundational questions that are significant when undertaking qualitative inquiry in the family business field. In the horizontal rows are questions concerning: (a) the research objectives under investigation; (b) the level of analysis being sought; and (c) the task of the researcher during the investigation. These are natural questions to address in any research project but when reflected upon in the light of the questions/issues outlined in the columns of Table 3 (i.e., (i) actions/ understandings from the point of view of situationalized individuals or groups; (ii) sensitivity to context; (iii) the role/ place of words, meanings or discourses; (iv) the role of the researcher), this helps to extend our engagement with qualitative inquiry in a way that goes beyond methods choice. In making explicit the responses to such questions we can also reflect upon the process of theory development-a feature which is important for scholarship. These foundational questions are now elaborated.

\subsection{Actions and understandings from the point of view of individuals or groups}

Referring to Table 3, the first task in all types of research is to clarify the research objectives or questions that can be addressed through qualitative inquiry. Examples of appropriate questions to ask are: What is the culture of this group? What tacit or mindful processes can be observed (Nordqvist et al., 2009; Zellweger, 2014)? What sources of conflict, solidarity or unspoken meanings or micropolitics of interactions are in play (Stewart, 2014, p.66)? How do people in this setting construct their social reality? What common set of symbols and understandings has emerged to give meaning to people's interactions? How do people make sense of their everyday activities? Qualitative researchers can focus on explicating actions, understandings, meanings and contradictions from the viewpoint of either significant individual people or groups of people in the family business. When undertaking qualitative research, this means focusing on verbal accounts, meanings, texts, words, linguistic phrases, images, symbols, signs, use of rhetoric, discourse and semiotic clusters of words either of individual people or collectives of individuals in dyads, alliances, kinship groups, or other interactive, social situations. Here, we see much potential in family business research especially if the research captures the interactions/dialogues/conversations/interrelationships in situ, as this is often the way that we can observe organizing processes unfolding and how people come to make sense of their everyday life in the organization.

\subsection{Display how words, language, symbols, and images are constitutive of meaning}

Having established the key set of questions that can be evaluated qualitatively, researchers have an important choice to make regarding how they 'present' their qualitative research material. One option is to present research material in verbal accounts, texts or images, semiotic clusters of words as objective 'data' that represents what is occurring within that organization. Here, there is more attention to how words signify certain kinds of behaviors (i.e. culture, familiness, professional management, etc.), rather than the meanings behind the words. Alternatively, in a more constructionist perspective, the qualitative researcher would emphasize how, through language, linguistic processes, signs or rhetoric, people (either individually or interactively) come to constitute meaning in relation to context. This latter perspective embodies a philosophical assumption that social reality is constructed interactively through symbolic and dialogic processes. 
Table 3

Foundational questions for realizing the potential of qualitative research in the family business field.

\begin{tabular}{|c|c|c|c|c|c|}
\hline & $\begin{array}{l}\text { Actions and } \\
\text { understandings } \\
\text { from the point of } \\
\text { view of individuals } \\
\text { or groups }\end{array}$ & $\begin{array}{l}\text { Sensitivity to context } \\
\text { process and gaining a } \\
\text { holistic view }\end{array}$ & $\begin{array}{l}\text { Display how words, } \\
\text { language, symbols, and } \\
\text { images are constitutive of } \\
\text { meaning }\end{array}$ & $\begin{array}{l}\text { Role of the qualitative } \\
\text { researcher }\end{array}$ & Theory development \\
\hline $\begin{array}{l}\text { 1. What are my } \\
\text { research } \\
\text { objectives? }\end{array}$ & $\begin{array}{l}\text { To explicate the } \\
\text { actions and } \\
\text { understandings } \\
\text { from the point of } \\
\text { view of the } \\
\text { individuals or } \\
\text { groups of people. }\end{array}$ & $\begin{array}{l}\text { a) To demonstrate } \\
\text { sensitivity to context, } \\
\text { process and gain a } \\
\text { holistic view of social } \\
\text { phenomena. } \\
\text { And/or } \\
\text { b) To work out the } \\
\text { arrangement and } \\
\text { structuring of } \\
\text { relationships, patterns, } \\
\text { rules and logics in } \\
\text { relation to context. }\end{array}$ & $\begin{array}{l}\text { a) To display the accounts, } \\
\text { logics patterns, structures } \& \\
\text { interactions reported during } \\
\text { fieldwork. } \\
\text { And } \\
\text { b) To maintain field work } \\
\text { accounts in their original } \\
\text { forms throughout the study. }\end{array}$ & $\begin{array}{l}\text { To make transparent the } \\
\text { researcher-stance during the } \\
\text { research process and report } \\
\text { the audit trail from sensitizing } \\
\text { concepts to fieldwork activity } \\
\text { and analysis. }{ }^{41}\end{array}$ & $\begin{array}{l}\text { a) To induce theory from the } \\
\text { contextualized accounts of } \\
\text { respondents. } \\
\text { Or, } \\
\text { b) To build theory iteratively } \\
\text { with concepts as insights } \\
\text { emerge from local context. } \\
\text { Or, } \\
\text { c) To test theory deductively } \\
\text { through the application of pre- } \\
\text { developed propositions to } \\
\text { insights from local context. }\end{array}$ \\
\hline $\begin{array}{l}\text { 2. What is my level } \\
\text { of analysis? }\end{array}$ & $\begin{array}{l}\text { a) Individual sense- } \\
\text { making. } \\
\text { And/or } \\
\text { b) Dyads, groups, } \\
\text { networks alliances, } \\
\text { organizations and } \\
\text { other collectives of } \\
\text { individuals. }\end{array}$ & $\begin{array}{l}\text { a) Individuals in socio- } \\
\text { cultural context. } \\
\text { And/or } \\
\text { b) Collectivities, groups } \\
\text { of individual in socio- } \\
\text { cultural context(s). }\end{array}$ & $\begin{array}{l}\text { Verbal accounts, meanings, } \\
\text { texts, words, linguistic } \\
\text { phrases, images, symbols, } \\
\text { signs, use of rhetoric, } \\
\text { discourse, semiotic clusters } \\
\text { of words and meanings. }\end{array}$ & $\begin{array}{l}\text { a) Accounts reported or } \\
\text { observations made in a } \\
\text { particular socio-cultural } \\
\text { context. } \\
\text { Or, } \\
\text { b) The relationship } \\
\text { constructed with respondents. }\end{array}$ & $\begin{array}{l}\text { a) Presenting insights and } \\
\text { accounts as 'grounded theory'. } \\
\text { Or, } \\
\text { b) Iterative synthesis of } \\
\text { theoretical concepts with } \\
\text { fieldwork accounts and } \\
\text { experiences aided by } \\
\text { sensitization to the local context } \\
\text { Or, } \\
\text { c) Theory development is co- } \\
\text { constructed with respondents. }\end{array}$ \\
\hline $\begin{array}{l}\text { 3. What is my task } \\
\text { during the } \\
\text { research } \\
\text { process? }\end{array}$ & $\begin{array}{l}\text { a) To record the } \\
\text { accounts and } \\
\text { intentions of local } \\
\text { actors 'from the } \\
\text { inside'. } \\
\text { b) To listen and be } \\
\text { attentive to what is } \\
\text { being said. } \\
\text { c) To build rapport, } \\
\text { dialogue and } \\
\text { empathetic } \\
\text { awareness with } \\
\text { respondents. }\end{array}$ & $\begin{array}{l}\text { a) To record the } \\
\text { accounts and intentions } \\
\text { of local actors 'from the } \\
\text { inside' and to engage in } \\
\text { prolonged contact } \\
\text { within the field. } \\
\text { b) To undertake } \\
\text { repeated interactions in } \\
\text { the field. } \\
\text { c) To record actions/ } \\
\text { events over time. }\end{array}$ & $\begin{array}{l}\text { a) To assemble, cluster or } \\
\text { categorize qualitative } \\
\text { material into semiotic } \\
\text { segments in order to elicit } \\
\text { meaning, contrast/compare, } \\
\text { and to bestow patterns. } \\
\text { b) To maintain and privilege } \\
\text { the original fieldwork } \\
\text { accounts. And show the } \\
\text { intentionality of the } \\
\text { respondent(s). }\end{array}$ & $\begin{array}{l}\text { a) To remain 'neutral' and } \\
\text { collect data objectively. } \\
\text { Or, } \\
\text { b) To act 'vicariously' observing } \\
\text { and reporting others' accounts } \\
\text { through one's own } \\
\text { theoretically- informed } \\
\text { interpretations. } \\
\text { Or, } \\
\text { c) To construct fieldwork } \\
\text { process and analysis in } \\
\text { collaboration with } \\
\text { respondents. }\end{array}$ & $\begin{array}{l}\text { a) To suspend or 'bracket' } \\
\text { preconceptions about the topic } \\
\text { under discussion. } \\
\text { Or, } \\
\text { b) To examine as many } \\
\text { perspectives or interpretations } \\
\text { as is possible, and make choices } \\
\text { about which are more } \\
\text { compelling for theoretical } \\
\text { reasons or on grounds of internal } \\
\text { consistency. } \\
\text { Or, } \\
\text { c) To work closely with } \\
\text { respondents to develop theory in } \\
\text { line with their viewpoints and } \\
\text { perspectives. }\end{array}$ \\
\hline
\end{tabular}

\subsection{Sensitivity to context process and gaining a holistic view}

As discussed earlier, an important feature of qualitative inquiry is to demonstrate sensitivity to context and gain a holistic view of social phenomena. As Patton (2002, p.58-61) suggests, this helps to examine: How $\mathrm{X}$ perspective is manifest in this phenomenon, or how and why this system as a whole functions as it does; or under what conditions did a certain phenomenon take place that makes it possible to interpret its meaning? It also helps to work out the arrangement and structuring of relationships, patterns, rules and logics in relation to contextual factors. This means that it is important to move beyond the display of verbal accounts to a deeper examination of how certain logics, patterns and structuring influences appear to be shaping linguistic processes or interactions. Either way, an important feature of qualitative research is to maintain, as far as is possible, the fieldwork accounts in their original forms throughout the study and to describe for the reader the context within which such insights were observed.

\subsection{Role of the qualitative researcher}

Following this, if a constructionist theoretical stance is being adopted, it is necessary that the role of researcher is made explicit within the research report ${ }^{6}$. This can be done by reporting/analyzing the accounts or observations made in particular socio-political contexts (see theory development discussion below). But central to this is the need to make transparent the relationship and rapport constructed with respondents. One stance is to remain 'neutral' and collect material and accounts as it naturally occurs in an objective way as is possible. Here, the researcher might present insights and accounts as 'grounded theory' and suspend or 'bracket' preconceptions about the topic under study in order to privilege the localized accounts. Although some qualitative inquirers would argue that this is not really possible when interacting in the field, in that one's gender, class, ethnicity, way of speaking etc. is always evident and potentially shapes the nature of the fieldwork interaction, this might be preferable to those researchers who aim for the research to be as naturalist or neutral as possible.

Another stance, which is more common in qualitative inquiry, is that the researcher acts 'vicariously' observing and reporting others' accounts through one's own theoretically-informed interpretations. In these cases, there is an iterative synthesis of theoretical concepts with fieldwork accounts and experiences with sensitizing concepts from the literature. A third stance is to adopt a

\footnotetext{
${ }^{6}$ See Van Maanen, J. (2011). Tales of the field: On writing ethnography. University of Chicago Press.
} 
more collaborative approach to the fieldwork in a mode of coinquiry where the research questions, problematizations and theory development are co-constructed with family business stakeholders (rather than respondents) in the fieldwork setting. Two rare examples in family business research are: Friedman (1991) who explains how his research on sibling relationships was conducted through intertwined processes of research, consultation and self-examination; and Helin (2011) who speaks in a reflexive way about the 'living moments' experienced during family business meetings.

\subsection{Theory development}

In Table 3, we outline three possible implications for theory development: (a) To induce theory from the contextualized accounts of respondents; (b) To build theory iteratively with concepts/theories as insights emerge from local context; (c) To test theory deductively through the application of pre-developed propositions to insights from the local context. The mode of theory development and the extent to which we reify the data as 'representations' of organizational level phenomena are determined by the research objectives and the theoretical orientation of the inquirer. For example, as we saw in the extant qualitative family business research, researchers often simplify the qualitative insights drawn in order to explain a single truth or explanation about organizational performance or culture. This misses the possibility, however, for discussing how other explanations are potentially more compelling (and internally consistent) for that particular context.

\section{Conclusion}

In the preceding analysis, we have suggested ways in which there is scope to further enhance qualitative inquiry in family business. First, we identified five analytical categories drawn from Miles and Huberman (1994) that represent the key characteristics of qualitative research. We then utilized these categories to review the sample of qualitative family business studies, to identify both the strengths and limitations of qualitative research in the family business field. Second, we used these categories to examine the kinds of research questions and topics that were being addressed and to assess how these questions were being applied through the use of qualitative techniques. Having identified a series of gaps and limitations, we stressed the need to extend the potential of qualitative research in family business studies by addressing the foundational questions that underlie our methods choices.

\subsection{Planning for new futures}

In this final section, we discuss some areas within family business research where a more intensive use of qualitative inquiry would be particularly useful for uncovering important and overlooked phenomena. The three areas that we focus on are: (i) paradoxes and dualities; (ii) family business processes and execution and (iii) contextual and industry-specific aspects of family business behavior.

As noted earlier, the notion of paradox (Lewis, 2000; Smith \& Lewis, 2011) and the related notion of duality (Jackson, 1999) are very relevant topics for qualitative inquiry given the characteristics of family firms and their complex or 'Janus-faced' nature (Miller et al., 2015). Another distinctive feature of family firms is the interactions between the individual, the firm and the family. These interactions from various forces give rise to simultaneouslypresent tensions and paradoxes which change over time. This means that they cannot be managed in a 'one size fits all' solution, and their importance cannot be easily captured through conventional research approaches emphasizing variance rather than process (Poole \& Van de Ven, 1989). Closer attention to family business paradoxes and dualities through qualitative methodologies would help to demonstrate how various organizational processes are interconnected. It would also help to reconcile existing findings from quantitative studies and enhance our conceptual and practical understanding of the deeper foundational issues characterizing family business life and experiences. Even when quantitative studies reveal a potential family business paradox or duality through curvilinear relationships (e.g., Bolin, Pieper, \& Covin, 2015), the mechanisms and micro-foundations underlying that paradox can hardly be grasped without recurring to qualitative methodologies.

A second topical area where a more intensive use of qualitative inquiry would be particularly useful is related to family business processes and execution. By this we mean how social actors in family businesses: identify decisions and actions to resolve issues and problems, set organizational goals, delegate tasks and the sequence within which these issues are resolved and the accountabilities and deliverables demanded from each person involved (De Massis \& Kotlar, 2015). Considering that the involvement of the controlling family will necessarily introduce family dynamics into the organization, the decision making, strategy planning and implementation processes adopted by family firms may be distinctive as well. Currently, however, we know very little about how decisions are made or behaviors are manifested in family firms because the processes by which family firms execute their strategies and produce their distinctiveness remain understudied. Qualitative methodologies are well suited to fill this knowledge gap.

A third topical area in which qualitative research can be further extended relates to the contextual and industry-specific aspects of family business behavior. Individuals, families and organizations interact in numerous ways with peers and competitors, customers, regulators and other stakeholders who, collectively, are perceived as an industry. Such industries can differ in terms of their political, economic, socio-cultural and technological conditions (Dess, Ireland, \& Hitt, 1990). In turn, these differences are likely to shape the determinants, processes and outcomes of family business behavior. Moreover, the particularistic behavior of family firms is strongly intertwined with the goals, beliefs, heuristics, intuition, and accurate or inaccurate information that derive from individuals' experience within an industry. For example, behavioral perspectives in family business research suggest that the relationships of family business owners and managers with a high- versus low-tech sector can shape the way they engage in innovation (Gomez-Mejia, Campbell, Martin, Hoskisson, Makri, \& Sirmon, 2014).

Despite the increasing attention to the role of context in family business (e.g., Wright, Chrisman, Chua, \& Steier, 2014), and despite acknowledgement of how industry variables have long dominated individual-, group- and organization-level variables in empirical studies of family business behavior, the underlying mechanisms through which the industrial sector shapes family business behavior and the micro-strategies, routines and capabilities through which individuals, families, organizations and industries interact in conducting business activity remain largely under theorized and little understood. Qualitative inquiry has the potential to guide future family business research toward a deeper understanding of industry-specific determinants, processes and outcomes of family business behavior.

The selection of these topics serves to remind us about the potential of qualitative research for examining the 'microfoundations' (Gagné et al., 2014; Zahra et al., 2014) of family business structures and behaviors and for 'narrowing the micromacro gap' (Bamberger, 2008, p.840) in family business research. In addition, we argue that greater scrutiny about the foundational 
questions we are trying to address through qualitative inquiry is important because there is no 'single, monolithic approach to qualitative research and evaluation' (Patton, 2002, p.76) or accepted 'boilerplate' that standardizes the approach to and writing of qualitative research (Pratt, 2009, p.856). On the contrary, in qualitative inquiry there is: 'an exhilarating and [even] at times exhausting proliferation of types' (Patton, 2000, 76, referring to Page, 2000, p.3). This diversity and breadth is not only demonstrated by the range of methods available. It derives from the fact that the key principles of qualitative inquiry derive from various theoretical schools of thought (such as pragmatism, phenomenology, interpretivism, hermeneutics, symbolic interactionism, ethnomethodology, social constructionism and poststructuralism) that privilege (amongst other things) the subjective, the social, the contextual, the value laden, the ethical, the negotiated and the taken for granted. A key message behind this article is to encourage greater 'experimentation and creativity in the craft of qualitative research' (Pratt et al., 2009 p.857). This will help to promote the scholarship of micro-level research and to address those illusive processes that manifest themselves in contradictions, paradoxes, conflicts, mindfulness and the complexities that are central to the accountabilities of social actors who manage the obligations that come with being a member of a family and a business.

\section{References}

Ainsworth, S., \& Cox, J. W. (2003). Families divided: culture and control in small family business. Organization Studies, 24(9), 1463-1485.

Alvesson, M., \& Deetz, S. (2000). Doing critical management research. London: Sage. Alvesson, M., \& Sköldberg, K. (2000). Reflexive methodology: new vistas for qualitative research. London: Sage.

Bagwell, S. (2008). Transnational family networks and ethnic minority business development: The case of Vietnamese nail-shops in the UK. International Journa of Entrepreneurial Behaviour \& Research, 14(6), 377-394.

Bamberger, P. (2008). From the editors beyond contextualization: using context theories to narrow the micro-macro gap in management research. Academy of Management Journal, 51(5), 839-846.

Bolin, J. R., Pieper, T. M., \& Covin, J. G. (2015). CEO tenure and entrepreneurial orientation within family and nonfamily firms. Entrepreneurship Theory \& Practice . http://dx.doi.org/10.1111/etap.12150.

Brundin, E., \& Nordqvist, M. (2008). Beyond facts and figures: the role of emotions in boardroom dynamics. Corporate Governance: An International Review, 16(4), 326-341.

Bryman, A., \& Bell, E. (2007). Business research methods. New York: Oxford University Press.

Buchanan, D. A., \& Bryman, A. (2009). The sage handbook of organizational research methods. London: Sage.

Camblanne, L. (2013). Family vision and cognition: an illustration through forest owners' harvesting decisions. Journal of Family Business Strategy, 4(4), 245-259.

Chia, R., \& Tsouskas, H. (2003). Everything flows and nothing abides: towards a 'rhizomic' model of organizational change. Process Studies, 32(2), 196-224.

Chenail, R. J. (2009). Communicating your qualitative research better. Family Business Review, 22(2), 105-108.

Chirico, F. \& Nordqvist, M. (2010). Dynamic capabilities and trans-generational value creation in family firms: the role of organizational culture. International Small Business Journal, 28(5), 487-504.

Chrisman, J. J., Chua, J. H., De Massis, A., Frattini, F., \& Wright, M. (2015). The ability and willingness paradox in family firm innovation. Journal of Product Innovation Management, 32(3), 310-318.

Cole, P. M. (1997). Women in family business. Family Business Review, 10(4), 353-371

Colli, A. (2012). Contextualizing performances of family firms the perspective of business history. Family Business Review, 25(3), 243-257.

Corley, K. (2011). The coming of age for qualitative research: embracing the diversity of qualitative methods. Academy of Management Journal, 54(2), 233-237.

Dawson, A., \& Hjorth, D. (2012). Advancing family business research through narrative analysis. Family Business Review, 25(3), 339-355.

De Massis, A., Frattini, F., \& Lichtenthaler, U. (2013). Research on technological innovation in family firms: present debates and future directions. Family Business Review, 26(1), 10-31.

De Massis, A., Frattini, F., Pizzurno, E., \& Cassia, L. (2013). Product innovation in family vs. non-family firms: an exploratory analysis. Journal of Small Business Management . http://dx.doi.org/10.1111/jsbm.12068 (In press).

De Massis, A., \& Kotlar, J. (2015). Learning resources for family business education: A review and directions for future developments. Academy of Management Learning E' Education . http://dx.doi.org/10.5465/amle.2014.0246 (In press).
De Massis, A., \& Kotlar, J. (2014). The case study method in family business research: guidelines for qualitative scholarship. Journal of Family Business Strategy, 5(1), 15-29.

De Massis, A., Sharma, P., Chua, J. H., \& Chrisman, J. J. (2012). Family business studies: an annotated bibliography. Northhampton, MA: Edward Elgar.

DeAngelo, H., \& DeAngelo, L. (2000). Controlling stockholders and the disciplinary role of corporate payout policy: a study of the Times Mirror Company. Journal of Financial Economics, 56(2), 153-207.

Denzin, N. L., \& Lincoln, Y. (1994). Handbook of qualitative research. Thousand Oaks, CA: Sage.

Dess, G. G., Ireland, R. D., \& Hitt, M. A. (1990). Industry effects and strategic management research. Journal of Management, 16(1), 7-27.

Dyck, B., Mauws, M., Starke, F. A., \& Mischke, G. A. (2002). Passing the baton: The importance of sequence, timing, technique and communication in executive succession. Journal of Business Venturing, 17(2), 143-162.

Fenton, C., \& Langley, A. (2011). Strategy as practice and the narrative turn. Organization Studies, 32(9), 1171-1196.

Fletcher, D. E (2004). Family as a discursive resource for understanding the small family business. Understanding the small family business. London: Routledge pp. $1-16$.

Fletcher, D. E. (2014). Family business inquiry as a critical social science. In L. Melin, M. Nordqvist, \& P. Sharma (Eds.), The Sage handbook of family business London: Sage.

Fletcher, D. E. (2010). Life-making or risk taking? Co-preneurship and family business start-ups. International Small Business Journal, 28(5), 452-469.

Fletcher, D. E. (2000). Family and enterprise. In S. Carter, \& D. Jones-Evans (Eds.), Enterprise and small business: principles, practice and policy (pp. 155-165) London: Prentice Hall.

Furrer, O., Thomas, H., \& Goussevskaia, A. (2008). The structure and evolution of the strategic management field: a content analysis of 26 years of strategic management research. International Journal of Management Reviews, 10(1), 1-23.

Gagné, M., Sharma, P., \& De Massis, A. (2014). The Study of organizational behavior in family business. European Journal of Work and Organizational Psychology, 23 (5), 643-656.

Gluckman, M. (1961). Ethnographic data in British social anthropology. The Sociological Review, 9(1), 5-17.

Gomez-Mejia, L. R., Campbell, J. T., Martin, G., Hoskisson, R. E., Makri, M., \& Sirmon, D. G. (2014). Socioemotional wealth as a mixed gamble: revisiting family firm R\&D investments with the behavioral agency model. Entrepreneurship Theory and Practice, 38(6), 1351-1374.

Graves, C., \& Thomas, J. (2008). Determinants of the internationalization pathways of family firms: an examination of family influence. Family Business Review, 21 (2), 151-167.

Gubrium, J. F., \& Holstein, J. A. (1997). The new language of qualitative method. New York: Oxford University Press.

Hall, A., \& Nordqvist, M. (2008). Professional management in family businesses: toward an extended understanding. Family Business Review, 21(1), 51-69.

Hall, A., Melin, L., \& Nordqvist, M. (2001). Entrepreneurship as radical change in the family business: exploring the role of cultural patterns. Family Business Review, 14(3), 193-208.

Hedberg, P. R., \& Danes, S. M. (2012). Explorations of dynamic power processes within copreneurial couples. Journal of Family Business Strategy, 3(4), 228-238.

Helin, J. (2011). Living moments in family meetings: a process study in the family business context. Doctoral dissertation. Jonkoping, Sweden: Jonkoping Business School.

Howorth, C., Westhead, P., \& Wright, M. (2004). Buyouts, information asymmetry and the family management dyad. Journal of Busines Venturing, 19(4), 509-534.

Irava, W. J., \& Moores, K. (2010). Clarifying the strategic advantage of familiness: unbundling its dimensions and highlighting its paradoxes. Journal of Family Business Strategy, 1(3), 131-144.

Jackson, W. A. (1999). Dualism, duality and the complexity of economic institutions. International Journal of Social Economics, 26(4), 545-558.

Jennings, J. E., Breitkreuz, R. S., \& Jones, A. E. (2014). Theories from family science: a review and a roadmap for family business research. The SAGE handbook of family business. Thousand Oaks, CA: SAGE Publications648-655.

Johannisson, B., \& Huse, M. (2000). Recruiting outside board members in the small family business: an ideological challenge. Entrepreneurship Regional Development, 12(4), 353-378.

Karra, N., Tracey, P., \& Phillips, N. (2006). Altruism and agency in the family firm: exploring the role of family, kinship, and ethnicity. Entrepreneurship Theory $\mathcal{E}$ Practice, 30(6), 861-877.

Kotlar, J., \& De Massis, A. (2013). Goal setting in family firms: Goal diversity, social interactions, and collective commitment to family-centered goals. Entrepreneurship Theory and Practice, 37(6), 1263-1288.

Lambrecht, J. (2005). Multigenerational transition in family businesses: a new explanatory model. Family Business Review, 18(4), 267-282.

Lewis, M. W. (2000). Exploring paradox: toward a more comprehensive guide. Academy of Management Review, 25(4), 760-776.

Malkki, L. H. (2007). Tradition and improvisation in ethnographic field research. In A. Cerwonka, \& L. H. Malkki (Eds.), Improvising theory: Process and Temporality in Ethnographic Fieldwork (pp. 162-187). Chicago IL: University of Chicago Press.

Martinez, M., \& Aldrich, H. (2014). Sociological theories applied to family business research. The SAGE handbook of family business. Thousand Oaks, CA: SAGE Publications648-655.

Meier, O., \& Schier, G. (2014). Family firm succession: Lessons from failures in external party takeovers. Journal of Family Business Strategy, 5(4), 372-383. 
Melin, L., \& Nordqvist, M. (2007). The reflexive dynamics of institutionalization: The case of the family business. Strategic Organization, 5(3), 321-333.

Miles, M. B., \& Huberman, A. M. (1994). Qualitative data analysis: an expanded sourcebook. Beverly Hills. CA: Sage Publications.

Miller, D., Steier, L., \& Le Breton-Miller, I. (2003). Lost in time: intergenerational succession, change, and failure in family business. Journal of Business Venturing, 18(4), 513-531.

Miller, D., Wright, M., Le Breton-Miller, I., Scholes, L. (2015). Resources and innovation in family businesses: The Janus-face of family socio-emotional preferences. California Management Review (forthcoming).

Murphy, L., \& Lambrechts, F. (2015). Investigating the actual career decisions of the next generation: the impact of family business involvement. Journal of Family Business Strategy . http://dx.doi.org/10.1016/j.jfbs.2014.10.00.

Murray, B. (2003). The succession transition process: a longitudinal perspective. Family Business Review, 16(1), 17-33.

Neergaard, H., Ulhøi, J. P. (2007). Handbook of qualitative research methods in entrepreneurship. Cheltenham, U.K.: Elgar.

Nordqvist, M. (2012). Understanding strategy processes in family firms: exploring the roles of actors and arenas. International Small Business Journal, $30(1), 24-40$.

Nordqvist, M., \& Melin, L. (2010). The promise of the strategy as practice perspective for family business strategy research. Journal of Family Business Strategy, 1(1), $15-25$.

Nordqvist, M., Hall, A., \& Melin, L. (2009). Qualitative research on family businesses: the relevance and usefulness of the interpretive approach. Journal of Management \& Organization, 15(3), 294-308.

Ordanini, A., Rubera, G., \& DeFillippi, R. (2008). The many moods of interorganizational imitation: a critical review. International Journal of Management Reviews, 10(4), 375-398.

Page, R. N. (2000). Future directions in qualitative research. Harvard Educational Review, 70, 100-108.

Parada, M. J., Nordqvist, M., \& Gimeno, A. (2010). Institutionalizing the family business: the role of professional associations in fostering a change of values. Family Business Review, 23(4), 355-372.

Patton, M. Q. (2002). Qualitative research and education methods. Thousand Oaks, CA: Sage.

Podsakoff, P. M., Mackenzie, S. B., Bachrach, D. G., \& Podsakoff, N. P. (2005). The influence of management journals in the 1980 and1990s. Strategic Management Journal, 26(5), 473-488.

Poole, M. S., \& Van de Ven, A. H. (1989). Using paradox to build management and organizational theories. Academy of Management Review, 14(4), 562-578.

Pratt, M. G. (2009). From the editors: for the lack of a boilerplate: tips on writing up (and reviewing) qualitative research. Academy of Management Journal, 52(5), $856-862$.

Reay, T., \& Zhang, Z. (2014). Qualitative methods in family business research. In L. Melin, M. Nordqvist, \& P. Sharma (Eds.), The Sage Handbook of Family Business (pp. 573-593). London: Sage.
Salvato, C., Chirico, F., \& Sharma, P. (2010). A farewell to the business. Entrepreneurship \& regional development, 22(3-4), 321-348.

Schlepphorst, S., \& Moog, P. (2014). Left in the dark: family successors' requirement profiles in the family business succession process. Journal of Family Business Strategy, 5(4), 358-371.

Schwandt, T. A. (1997). Qualitative Inquiry: A dictionary of terms. Thousand Oaks, CA: Sage.

Silverman, D. (1985). Qualitative methodology and sociology, Aldershot: Gower.

Smith, W. K., \& Lewis, M. W. (2011). Toward a theory of paradox: a dynamic equilibrium model of organizing. Academy of Management Review, 36(2), 381403.

Steier, L. (2001a). Family firms, plural forms of governance, and the evolving role of trust. Family Business Review, 14(4), 353-368.

Steier, L. (2001b). Next-generation entrepreneurs and succession: an exploratory study of modes and means of managing social capital. Family Business Review, 14 (3), 259-276.

Steier, L. P., \& Miller, D. (2010). Pre-and post-succession governance philosophies in entrepreneurial family firms. Journal of Family Business Strategy, 1(3), 145-154.

Stewart, A. (1998). The ethnographer's method. Newbury Park. CA: Sage Publications.

Stewart, A. (2003). Help one another, use one another: toward an anthropology of family business. Entrepreneurship Theory and Practice, 27(4), 383-396.

Stewart, A. (2014). The anthropology of family business: An imagined ideal. In L. Melin, M. Nordqvist, \& P. Sharma (Eds.), SAGE handbook of family business (pp. 66-82). Newbury Park, CA: Sage.

Thorpe, R., \& Holt, R. (2008). The Sage dictionary of qualitative management research. London: Sage.

Tsang, E. W. (2002). Learning from overseas venturing experience: the case of Chinese family businesses. Journal of Business Venturing, 17(1), 21-40.

Vera, C. F., \& Dean, M. A. (2005). An examination of the challenges daughters face in family business succession. Family Business Review, 18(4), 321-345.

Von Schlippe, A., Schneewind, K.A. (2014). 'Theories from family psychology and family therapy. In: The SAGE handbook of family business (pp. 648-655). SAGE Publications Thousand Oaks, CA.

Weick, K. (1995). Sensemaking in organizations. Thousand Oaks, CA:Sage.

Welsh, D. H. B., Memili, E., Rosplock, K., Roure, J., \& Seguardo, J. L. (2013). Perceptions of entrepreneurship across generations in family offices: a stewardship theory perspective. Journal of Family Business Strategy, 4(3), 213-226.

Wood, M. (2002). Mind the gap: a processual reconsideration of organizational knowledge. Organization, 9, 151-171.

Wright, M., Chrisman, J. J., Chua, J. H., \& Steier, L. P. (2014). Family enterprise and context. Entrepreneurship Theory and Practice, 38(6), 1247-1260.

Zahra, S. A., Wright, M., \& Abdelgawad, S. G. (2014). Contextualization and the advancement of entrepreneurship research. International Small Business Journal 0266242613519807.

Zellweger, T. (2014). Toward a Paradox Perspective of Family Firms: the Moderating Role of Collective Mindfulness of Controlling Families. In The SAGE handbook of family business (pp. 648-655). SAGE Publications Thousand Oaks, CA. 